\title{
Production and cost analysis of two harvesting systems in central Appalachia
}

\author{
Charles Robert Long \\ West Virginia University
}

Follow this and additional works at: https://researchrepository.wvu.edu/etd

\section{Recommended Citation}

Long, Charles Robert, "Production and cost analysis of two harvesting systems in central Appalachia" (2003). Graduate Theses, Dissertations, and Problem Reports. 1327.

https://researchrepository.wvu.edu/etd/1327

This Thesis is protected by copyright and/or related rights. It has been brought to you by the The Research Repository @ WVU with permission from the rights-holder(s). You are free to use this Thesis in any way that is permitted by the copyright and related rights legislation that applies to your use. For other uses you must obtain permission from the rights-holder(s) directly, unless additional rights are indicated by a Creative Commons license in the record and/ or on the work itself. This Thesis has been accepted for inclusion in WVU Graduate Theses, Dissertations, and Problem Reports collection by an authorized administrator of The Research Repository @ WVU. For more information, please contact researchrepository@mail.wvu.edu. 
PRODUCTION AND COST ANALYSIS OF TWO HARVESTING SYSTEMS IN

CENTRAL APPALACHIA

Charles R. Long

Thesis submitted to the Davis College of Agriculture, Forestry, and Consumer Sciences

at West Virginia University

in partial fulfillment of the requirements

for the degree of

Master of Science

in

Forestry

Dr. Jingxin Wang, Committee Chairperson

Dr. Joseph McNeel

Dr. Darrell Dean

Wood Industries

Morgantown, West Virginia

2003

Keywords: Production, Cost, Time Study, Timber Harvesting, Forest Operations 


\section{ABSTRACT \\ PRODUCTION AND COST ANALYSIS OF TWO HARVESTING SYSTEMS IN CENTRAL APPALACHIA}

\section{By Charles R. Long}

Cost and productivity are major factors when considering which type of harvesting system to operate. Observations were conducted on manual and mechanized harvesting operations in central Appalachian hardwood forest sites in order to obtain time study data. Production and cost analysis were conducted on the harvesting system data in order to compare the two systems. Chainsaw felling productivity was $363.4 \mathrm{ft}^{3} / \mathrm{PMH}$ (2180.4 bdft/PMH) and unit cost was $\$ 0.08 / \mathrm{ft}^{3}$ (\$0.013/bdft). Cable skidding productivity was $289.4 \mathrm{ft} 3 / \mathrm{PMH}(1736.4 \mathrm{bdft} / \mathrm{PMH})$ and unit cost was $\$ 0.28 / \mathrm{ft}^{3}$ (\$0.05/bdft). Manual harvesting system productivity was $181.7 \mathrm{ft}^{3} / \mathrm{SMH}(1090.2$ bdft/SMH) and unit cost was $\$ 0.36 / \mathrm{ft}^{3}$ (\$0.06/bdft). Feller-buncher felling productivity was $1266.6 \mathrm{ft} 3 / \mathrm{PMH}(7599.6 \mathrm{bdft} / \mathrm{PMH})$ and unit cost was $\$ 0.08 / \mathrm{ft}^{3}(\$ 0.013 / \mathrm{bdft})$. Productivity of top/delimbing with chainsaws after feller-buncher felling was 726.30 $\mathrm{ft}^{3} / \mathrm{PMH}(4357.8 \mathrm{bdft} / \mathrm{PMH})$ and unit cost was $\$ 0.04 / \mathrm{ft}^{3}$ (\$0.007/bdft). Grapple skidding productivity was $512.1 \mathrm{ft} 3 / \mathrm{PMH}(3072.6 \mathrm{bdft} / \mathrm{PMH})$ and unit cost was $\$ 0.16 / \mathrm{ft}^{3}$ (\$0.03/bdft). Mechanized harvesting system productivity was $716.94 \mathrm{ft}^{3} / \mathrm{SMH}$ (4301.6 bdft/SMH) and unit cost was $\$ 0.29 / \mathrm{ft}^{3}$ (\$0.05/bdft). Results indicated that although hourly costs of operation were considerably higher for the mechanized system than the manual system, cost per unit volume was only $\$ 0.07 / \mathrm{ft}^{3}$ (\$11.6/MBF) lower for the mechanized system. 


\section{DEDICATION}

I would like to dedicate this work to my wife, Sharon, my parents, Lynn and Judy, and my parents-in-law, Jo Ann and Jimmy Richmond. Their constant support and encouragement are what made the completion of this work possible. When it looked like I would not finish, they kept me going. 


\section{ACKNOWLEDGMENTS}

I would like to thank the USDA Forest Service Northeastern Research Station for the funding of this project. Thanks to Dr. Jingxin Wang, Dr. Joseph McNeel, and Dr. Darrell Dean of West Virginia University, and Dr. John Baumgras of the USDA Forest Service, for their support and guidance throughout this project. I would like to especially thank Dr. Wang for taking on the duty of being my major professor. Additional thanks go to Tom Crickenberger, of TrusJoist MacMillan, and MeadWestvaco for access to observe their logging contractors.

Thanks to Mark Jones for sleeping in a tent for 3 months while helping me in the exhaustive data collection process. Also, thanks to Bill Beatty, Jeremy Jones, Steve Perkins, Mike Vanderberg, Shaun Allen, and all of the other guys who pitched in when I needed help collecting data. Lastly, thanks to Bob Driscole and Mike Boyce for their help in getting a harvest conducted on the university forest. 


\section{TABLE OF CONTENTS}

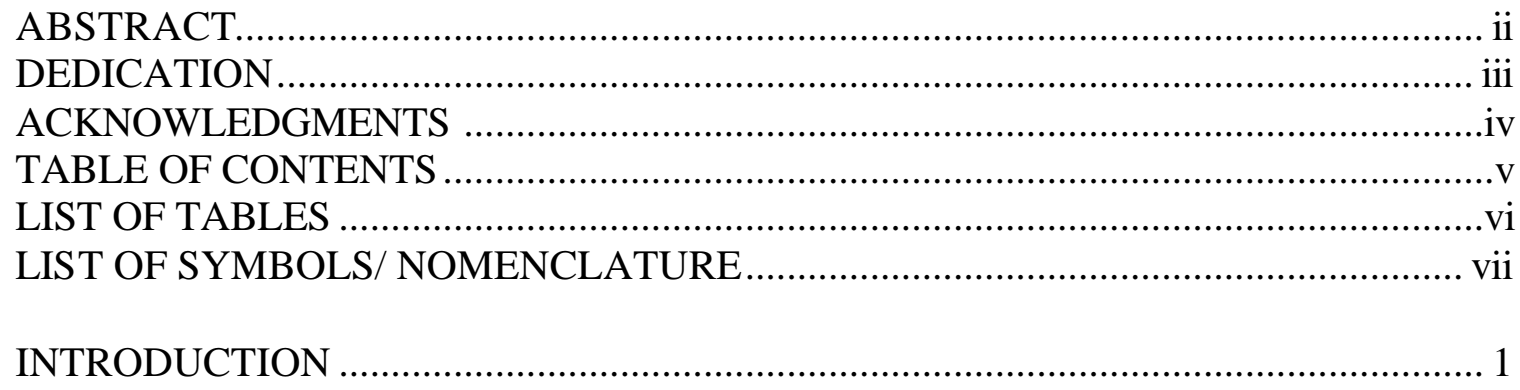

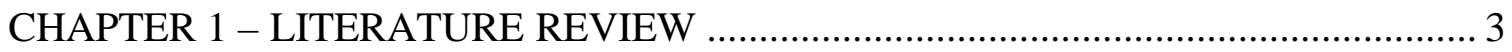

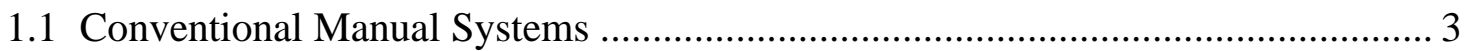

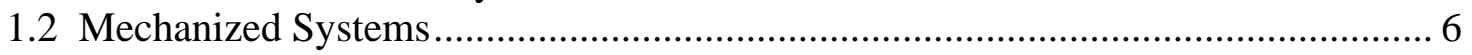

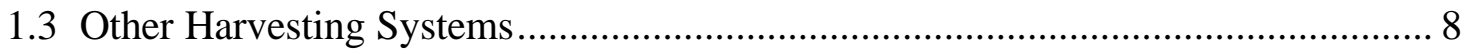

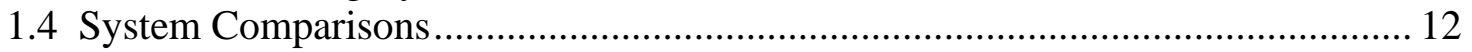

1.5 Computer-Based Time Study......................................................................... 14

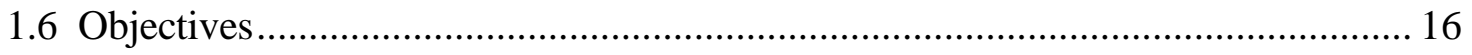

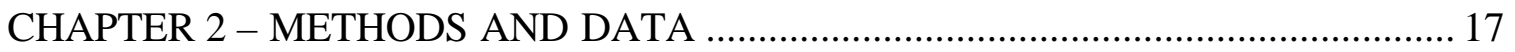

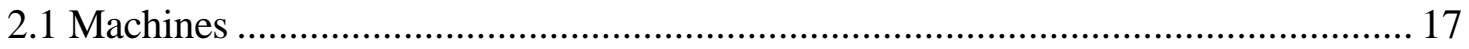

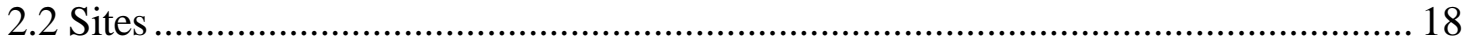

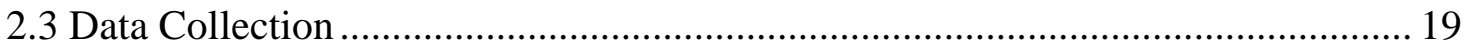

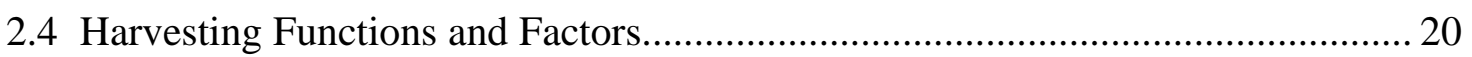

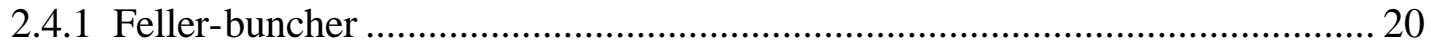

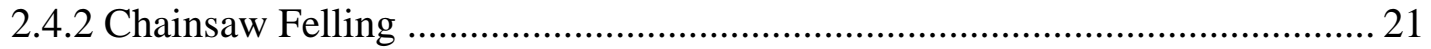

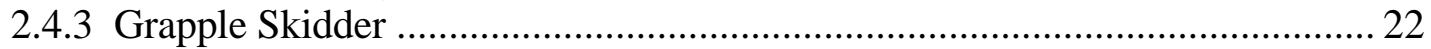

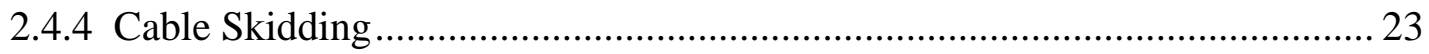

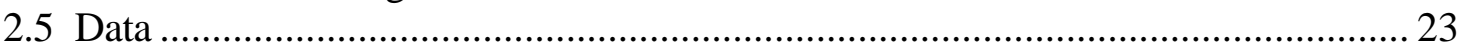

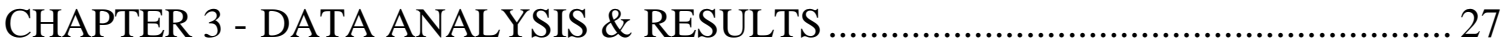

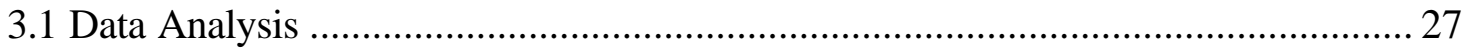

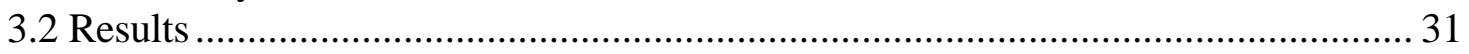

3.2.1 Productivities of Harvesting Machines ........................................................ 31

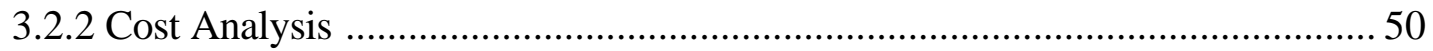

CHAPTER 4 - CONCLUSIONS AND DISCUSSION ……………………………...... 55

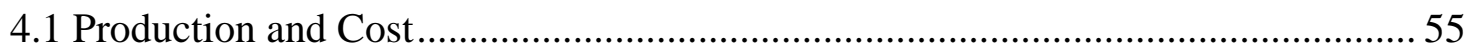

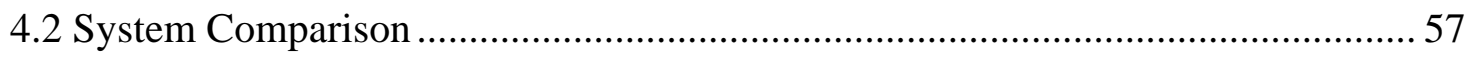

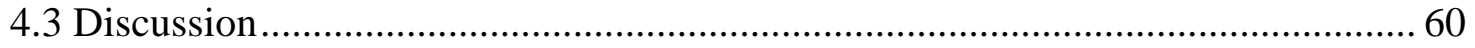

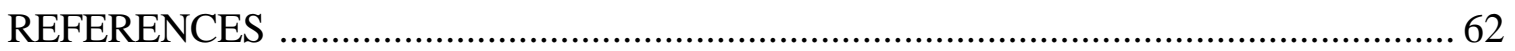

APPENDIX A: TIME STUDY DATA LOGGER INFORMATION .............................. 68

APPENDIX B: DATA COLLECTION SHEETS ………………………………...... 70

APPENDIX C: SAS CODE USED IN DATA ANALYSIS ......................................... 75 


\section{LIST OF TABLES}

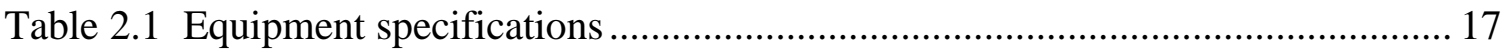

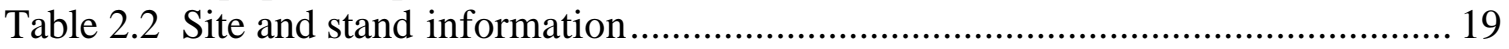

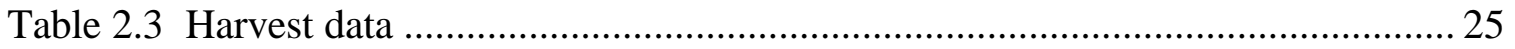

Table 3.1 - Means and significance levels of statistics for the manual felling during time

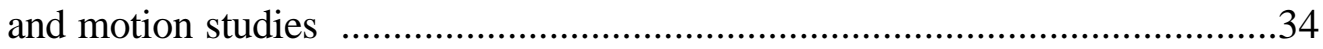

Table 3.2 - Models to estimate manual felling times and productivities ..........................34

Table 3.3 - Means and significance levels of statistics for the cable skidding during time

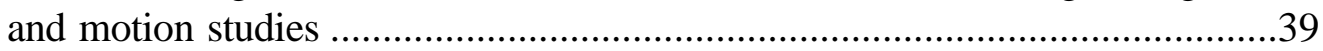

Table 3.4 - Models to estimate cable skidding times and productivities ..........................40

Table 3.5 - Means and significance levels of statistics for feller-buncher felling during time and motion studies ...........................................................................44

Table 3.6 - Models to estimate feller-buncher felling times and productivities ................44

Table 3.7 - Means and significance levels of statistics for grapple skidding during time and motion studies ...............................................................................49

Table 3.8 - Models to estimate grapple skidding times and productivities ......................50

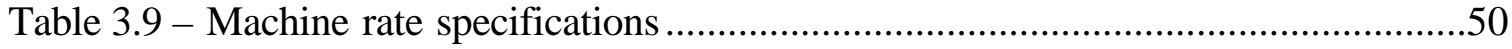

Table 3.10 - Manual harvesting machine rate calculations ........................................52

Table 3.11 - Mechanized harvesting machine rate calculations ...................................54

Table 4.1 - Production and cost of balanced systems .............................................60 


\title{
LIST OF SYMBOLS/ NOMENCLATURE
}

\author{
1. DBH .......................................... Diameter at Breast Height \\ 2. PMH ..........................................Productive Machine Hours \\ 3. SMH ...........................................Scheduled Machine Hours \\ 4. UT …..........................................Utilization
}




\section{INTRODUCTION}

Manual felling with a chainsaw and skidding with ground-based cable skidders is the harvesting system most commonly used in the Appalachian hardwood region, but the need for increased production and safety has some companies looking at mechanized alternatives such as feller-buncher/ grapple skidder systems. In the south, harvesting operations have moved quickly to complete mechanization with highly productive equipment in the past 25 years (McDonald et al., 2000). As a result of that trend, sawhead feller-bunchers and grapple skidders have become standard equipment on many Southern harvesting operations (Greene and McNeel, 1991). Being relatively new to the hardwood region, little if any research has been conducted to examine the production and cost effectiveness of the feller-buncher/ grapple skidder system when used on the terrain and with tree species common to this region.

It has been shown that the more mechanized the harvesting system, the more productive it usually is. A drawback is that as mechanization increased, costs also increased (Blinn et al., 1986). Site conditions are also a problem when using this type of system. Feller-bunchers can work on relatively steep slopes, but it is not known how cost effective it is to use them in that manner. Also, grapple skidders can only skid logs they can drive to. Steep slopes make that impossible in some cases. Characteristics of the tree species in this region may also be a problem. Feller bunchers are appropriately used for cutting pine trees since they have straight boles and relatively small branches. In the Central Appalachian region they have to cut trees that might be leaning and crown weight is usually very heavy. This makes for placement of trees after cutting and travel while carrying trees difficult, especially on steep slopes. 
In order to identify the production/cost effectiveness of using a feller buncher/ grapple skidder harvesting system and compare it with a manual harvesting system, a chainsaw felling/cable skidder skidding sys tem and a feller-buncher felling/grapple skidder skidding system were investigated in the Central Appalachian hardwood region. Results can help loggers and logging managers compare this system to other harvesting systems and choose an appropriate one to improve the operations in the region. 


\section{CHAPTER 1 - LITERATURE REVIEW}

The need for faster production, lower cost of logging, and environmental protection has increased rapidly in recent years. This has many looking for the cure-all system for harvesting timber. There have been many studies on mechanized harvesting in the South and yarding systems in the Pacific Northwest but little research has been done on mechanical systems in the Northeastern US. The common research done on these systems is in the form of time studies. The use of time study techniques aid in finding more economical ways of harvesting timber. The more that is learned about where time lost during the harvesting operation, the easier it will be to save money by eliminating the delays. Gibson and Rodenberg (1975) improved continuous time study by introducing a system of techniques which allowed time and motion data to be collected on harvesting operations more easily. They also designed forms to ease the collection of the data in the field. They introduced techniques for studying mechanized felling with a feller-buncher, ground based skidding with a cable or grapple skidder, and loading trucks with a heel-boom loader. These techniques were then put into use by researchers wanting to perform production and cost analysis on logging operations.

\subsection{Conventional Manual Systems}

Jones (1983) conducted a continuous and gross time study on three thinnings in northern West Virginia using Gibson and Rodenberg's techniques. The 60-acre treatment area was divided into twenty 3 -acre plots. Three thinning treatments $(75,60$, and 45 percent residual stocking per acre) were used. The harvest comprised of manual felling 
with a chainsaw and ground-based skidding with a cable skidder. The gross and continuous time studies showed that the thinning treatments significantly influenced felling and skidding production times. He concluded that, although costly, thinning hardwood stands is a good way of improving and increasing the nation's supply of hardwood timber supply. Brock et al. (1986) produced regression equations based on time study data, which can be used for estimating production rates and costs for similar thinning operations. Production equations for felling at the three thinning levels of 75,60 and 45 percent residual stocking per acre were derived. They also provided a monogram for estimating felling and skidding costs when using the recommended $60 \%$ residual stocking treatment.

Howard (1987) took a different approach to estimating timber harvesting production and cost with cable skidders by collecting shift-level data on fuel consumption, repairs, maintenance, and other operating costs and combined that with phone survey data. A model was created using the analysis of these costs and detailed production studies done in the past. This model was used to study the effect of timber size and species on logging costs and profitability. It was found that tree size had the greatest effect on skidding costs and species only affected costs in felling. Howard stated that the results can be used to establish contract rates and establish merchantability rates based on stand characteristics.

Another hardwood thinning production analysis was done by Huyler and LeDoux (1991) using small tractors instead of larger ground-based skidders. Five small tractors were used in the study. Productivity and cost of each was found and compared using a computer program. The study showed that small-scale harvesting machines are feasible 
but type of machine and careful site selection and layout are critical to ensure a profitable operation. It also showed that when compared to the larger equipment, these small tractors were more suitable and economic in thinning of small stands, with less soil compaction and less residual stand damage.

Many production/cost studies have been conducted in harvesting planted pine stands. Kluender and Stokes (1996) conducted a time study on a southern pine harvest consisting of manual felling, grapple skidding, and cable skidding. The harvest method ranged from clearcutting to single-tree selection and the proportion of basal area removed was used to measure harvest intensity. For felling, tree diameter was found to be the biggest factor in estimating felling time but distance between trees and harvest intensity were also important. For skidding, total distance traveled and stems per load were factors for all skidders. Harvest intensity was not a factor where cable skidders worked alone while skidder horsepower was only a factor where cable skidders worked alone. Elemental time and cost equations were derived using these factors. Average DBH of the harvested trees played the biggest role when determining productivity. A threshold tree size of $30 \mathrm{~cm}$ DBH was found, with harvesting costs changing little above that size. Lortz et al. (1997) did further analysis of southern pine felling and produced several equations for estimating felling times and productivity. They, however, only used DBH as the predictor in the equations since it had the greatest effect on felling.

Kluender et al. (1997) found that grapple skidders "were consistently faster and more productive than cable skidders." Harvest intensity affected grapple skidding productivity but not cable skidding productivity. This was explained by the fact that the grapple skidder had to approach ever stem individually while the cable skidder had some 
reach. While working together, they found that grapple skidding productivity stayed the same, while cable skidding became more productive.

Skidding is directly constrained by the number of pieces and maximum volume per turn. Peters (1990) used the load curve intercept method to explain effect of average piece size on skidding productivity and cost. Brinker et al. (1996) used four tire sizes (28L-26, 30.5L-32, 67x34.00-25, and 66x43.00-25) to examine their effects on skidding productivity and costs. Recently, there has been an interest in changing from the typical $71.4 \mathrm{~cm}$ wide skidder tire to a wider tire in hopes of increased productivity and reduced site impacts. This study showed that, on dry sites, there were no significant differences in productivities of skidders using wider tires when compared to those using more narrow tires.

\subsection{Mechanized Systems}

Mechanized harvesting systems using feller-bunchers and grapple skidders are growing in numbers in the northeast but have been commonly used in the South for years. Greene and McNeel (1991) examined productivity and cost of three different types of sawheads (chain-and-bar, intermittent-disk, and continuous-disk) used on feller-bunchers in the South. They found that continuous-disk sawheads were the fastest, followed closely by intermittent-disk and chain-and-bar sawheads. Move-and-sever time equations were developed for feller-bunchers using each type of sawhead. Even though continuous-disk sawheads were fastest, they suggested using intermittent or chain-andbar sawheads when operating in large timber or on rock or steep terrain due to the fact that the continuous disk may take considerable damage in these areas. 
Lanford and Stokes (1996) compared two harvesting systems, a fellerbuncher/grapple skidder system and a harvester/forwarder system, when thinning an 18year-old loblolly pine plantation. The harvester cut trees into 7.5-foot lengths or cut to length pulpwood. Weekly production rates were highest for the skidding system at 261 cords followed by the forwarding system with cut-to-length wood at 249 cords and the 7.5 -foot wood at 200 cords. Costs per cord for the skidder system was $\$ 0.14$ higher than the forwarding system using cut-to-length wood and $\$ 3.77$ lower than the forwarding system using 7.5 foot wood.

Wilhoit and Rummer (1999) indicated that large-scale mechanized systems might not be suited for smaller tracts of timber and small-scale operations should be looked at to replace the large systems for this type of harvest. Depending on the cost per unit of wood produced, they recommend different types of operations. Some of these suggestions are a small skid-steer machine with a chainsaw head combined with a tractor with grapple attachment or a single machine operation using a rubber-tracked machine with harvesting head and logging trailer. One of their main points is to keep capital low while maintaining the safe ty and productivity of a mechanized system.

The conventional manual logging operations are usually considered to be dangerous. Workers compensations rates are extremely high and can force some smaller operations out of business. Shaffer and Milburn (1999) looked at how mechanization of logging operations, especially feller-buncher/grapple skidder systems, has reduced the amount of injuries on the job. They found that chainsaw delimbing is most hazardous in partially mechanized systems. On fully mechanized jobs, felling/delimbing the 
occasional large tree caused a substantial number of injuries. They also found injuries mounting and dismounting equipment common.

\subsection{Other Harvesting Systems}

While ground-based systems are more commonly used, yarding systems have been looked at as a way to reduce environmental impacts in the Appalachian hardwood region. Kochenderfer and Wendel (1980) did a cost analysis on a truck-mounted crane used on a 30-acre tract in the Monongahela National Forest. They found that total logging costs were comparable to that of reported skidder systems. They did find differences between the systems in that the crane required fewer roads, caused less residual stand damage, and caused less harvested log damage since they were not skidded. Sediment production of the stand was measured and was comparable to that of skidding systems. Also they speculated that investment costs are less for this type of system as opposed to a skidding system because instead of purchasing a skidder and loader, the crane yards and loads the logs on trucks.

Fisher et al. (1980) analyzed the production and cost of a live skyline, The Ecologger, on a 62-acre tract in the Jefferson National Forest. The yarder was mounted on a 130 horsepower Tree Farmer C6D skidder. The average cycle time was 9.2 minutes with an average volume of 52.8 cubic feet of wood per cycle. Moving the carriage stop and repairing the cable were found to be the biggest delays in productivity. Yarding distance and the number of stems per turn were found to be the most significant factors in cycle time estimate equations. A total cost of $\$ 113.74$ per MBF (Doyle) was found for the system with individual costs of $\$ 12.34, \$ 2.39, \$ 16.23$, and $\$ 25.00$ per MBF (Doyle) 
were found for road construction, yarding, moving yarder, loading, and hauling, respectively. They indicated that yarding in this manner is more costly than ground skidding but causes less damage to the environment. When the need for less environmental impact exceeds the difference in harvesting costs between yarding and skidding, this system should be used.

Sarles and Whitenack (1984) revisited the use of the truck-mounted crane for thinning and clearcuts in Appalachia. The study was set up similar to the one done by Jones (1983) in which blocks were established using residual stocking levels of 45, 60, and 75 percent of initial stand density. The harvest consisted of manual felling and primary transport was done solely with the crane using chokers, tongs and a combination of both. For felling, production rates were found to be $6.9,7.0$, and 7.7 tons per hour for the 75, 60 and 45 percent- level respectively and 5.9 tons per hour for the clearcut method. Yarding production rates were 6.8, 6.4, and 6.3 tons per ho ur for the 75, 60, and 45 percent-level respectively and 4.6 tons per hour for the clearcut method. Average turn time for the yarder was over three times slower when using the chokers as apposed to the tongs while using a combination of both was only twice as slow. Total logging costs showed the 45 percent-level being the cheapest at $\$ 6.36$ per ton followed by the 60 percent-level at $\$ 6.65$ per ton, the 75 percent-level at $\$ 7.58$ per ton, and highest for the clearcut at $\$ 7.66$ per ton. The fact that the clearcut was most expensive was surprising. They explained that the decrease in productivity due to more slash and stumps was the reason for this. Just like Kochenderfer and Wendel (1980), Sarles and Whitenack (1984) found that the truck-mounted crane caused less residual stand damage and used fewer roads that traditional skidder systems would have. 
Baumgras and Peters (1985) experimented in the eastern hardwood region with yet another type of yarding equipment called the bitterroot miniyarder. Relatively small in size, it was an 18 horsepower skyline yarder used to yard small trees for fuelwood in the thinning of stands. A continuous time study was done on the yarder while logging a steep slope in Appalachia. The mean cycle time was 5.2 minutes at a mean yarding distance of 208 feet, mean turn volume of 11.6 cubic feet, and 2.3 pieces per turn. The yarding cost ranged from $\$ 18.00$ to $\$ 36.00$ per cunit. These costs depended greatly upon crew efficiency and yarding conditions.

As interest grew in the use of cable logging in eastern hardwoods, so did the amount of research done on the topic. LeDoux (1985) felt that the use of cable systems in this region could lead to lower production rates and higher costs if consideration of site conditions and equipment use was not taken. LeDoux and Butler (1981) examined how factors such as production costs, yarding distances, size of material cut, tree species, and silvicultural treatment used affected cable yarding by using a simulation program THIN. It was found that significant cost saving could be made by matching yarder type with stand conditions on a tract-by-tract bases. Six types of yarders were evaluated in their study including the Bitterroot Miniyarder, the Appalachian Thinner, the Koller K-300, the Ecologger I, the Urus 1000-3, and the Skylok 78. Tree size, yarding distance, and tree species greatly affected the yarder. The more costly the yarding equipment was to operate, the larger the average DBH and more valuable the species of the trees harvested needed to be in order to keep the operation profitable. For example, because of its small size the bitterroot miniyarder was found to be optimal on sites with trees averaging 7 to 9 inches in DBH. They also stressed that simulations are not perfect but that if these 
methods are used in the planning phase, the manager will be able to pick a yarding system that is more productive and profitable. LeDoux (1985) came up with stump to mill cost equations that can be applied when using one of the yarding systems mentioned previously. To do this he derived cost equations for the six types of yarders mentioned, for loading and for hauling. To use the equations, the user needs to know the mean DBH of trees to be harvested, average volume cut per acre, average slope yarding distance, type of yarder, the haul distance, truck class, and road class. LeDoux (1987) later added a seventh system, the Clearwater cable yarder developed by the USDA Forest Service, to the THIN model. It was field tested in the Eastern Adirondack region of New York. Detailed time and motion data was collected and the THIN yarding simulation was again used to develop the cost estimation equation. This yarder was comparative to the Appalachian Thinner with a DBH range of 7 to 10 inches, and with the Ecologger I and Koller K-300 in the range of 7 to 16 inches. It was found to be limited in capacity compared to other systems costing $\$ 95,000$. This small payload (1,250 pounds) was a disadvantage and made it impossible to bring in heavy loads to increase productivity.

In search of ways to improve yarding productivity while thinning western hemlock and Douglas-fir, McNeel and Dodd (1997) used Scandinavian techniques of manual felling. It was found that the Scandinavian felling method was much less productive than North American felling, but the yarding of the felled trees using the Scandinavian method was 1.7 times more productive than the yarding of those trees using North American techniques. Their cost estimates suggested that Scandinavian felling methods reduced costs of yarding by $\$ 2.50$ per ton delivered to roadside. 


\subsection{System Comparisons}

A way to compare multiple harvesting systems is very valuable in that it allows the harvest manager a way to choose which one is best for a certain situation. Blinn et al. (1986) compared five systems commonly used in the northern hardwood region. These systems were: (1) Manual felling, topping, delimbing, and bucking in woods with chainsaw and forwarding with forwarder; (2) Manual felling, topping, and delimbing with chainsaw, skidding with cable skidder, and bucking with chainsaw at landing; (3) Manual felling, topping, and delimbing with chainsaw, skidding with cable skidder, and bucking saw logs with chainsaw and all other material with hydraulic slasher at landing; (4) Fell and bunch with feller-buncher, delimb and top with chainsaw, skid with grapple skidder, and bucking saw logs with chainsaw and all other material with hydraulic slasher at landing ; (5) Fell and bunch with feller-buncher, delimb and top with chainsaw, skid with grapple skidder, and chip with whole-tree chipper The Harvesting System Simulator (Stuart 1981) was used to estimate system productivity, average cost per cord, and the harvest time per tract in 13 stands. Machines were modeled using previously collected data by 27 timber harvesting firms. All simulated harvests were clearcuts with $50 \%$ of the stand assumed to be aspen and the other $50 \%$ to be hardwoods. In pulpwoodonly harvests, system 1 and 2 showed the lowest productivity at .831 and .771 cords per employee per hour, respectively, and system 5 showed the highest productivity at 2.454 cords per employee per hour. Of the round wood harvests, productivity of 1.017 and 1.049 cords per employee per hour for systems 3 and 4 were significantly more productive than systems 1 and 2, with .746 and .771 cords per employee per hour. 
Wang et al. (1998) also used simulation to estimate elemental times, distance traveled, travel intensity, and hourly productivity for a combination of different harvesting methods, stand types, and equipment. The three felling methods (chainsaw, feller-buncher, and harvester) and two extraction methods (grapple skidder and forwarder) were examined while being used on three harvest intensities (clearcut, shelterwood, and single-tree selection). Main factors affecting felling productivity were mean DBH of trees remove, harvest intensity, and method. The main factors affecting extraction were payload and distance traveled.

Seeing the need for less environmental damage caused by harvesting systems, LeDoux and Huyler (2000) compared a Koller K-300 cable yarder, a cut-to-length (CTL) harvester and an A60F Holder tractor using ECOST (LeDoux 1985) and ECOST 3.0. ECOST and ECOST 3.0 are software programs that are used to model production rates, break-even piece sizes/costs, and operating costs. They found that using these systems would reduce soil compaction and minimize residual stand damage. Daily production was highest for the Koller K-300 at 3,360 $\mathrm{ft}^{3}$ followed by the CTL at 1,825 $\mathrm{ft}^{3}$ and the Holder tractor with 1,108 $\mathrm{ft}^{3}$. At $90 \%$ machine utilization, the Koller yarder had the highest break-even piece size at $7.64 \mathrm{ft}^{3}$, followed by the CTL at $4.63 \mathrm{ft}^{3}$ and the A60F at $3.74 \mathrm{ft}^{3}$.

Shaffer et al. (1993) studied group selections when harvested using fellerbuncher/cable skidding, chainsaw felling/cable skidding, and a skyline system and found that costs per ton were $\$ 14.13, \$ 15.33$, and $\$ 39.72$, respectively. They also found that production dropped significantly when harvesting group selections rather than conventional clearcuts and placed the cause on the "amount of unproductive time 
resulting from the impact of the small, dispersed, multiple-harvest areas." Hassler et al. (2000) revisited the effects of group selection on logging productivity. They conducted a study on ground-based skidding and found that size of the opening had little or no effect on skidding productivity.

\subsection{Computer-Based Time Study}

Howard and Gasson (1991) stated that time study is traditionally conducted using stopwatches and hand recording information such as elapsed times and environmental and operational factors. They developed a DOS-based computer program that utilizes handheld computers to collect time study data rather than using complicated forms. They reported that if handheld computers are to be used in time studies though, decisions must be made on what type of data should be collected with the program used. The actual program they created to collect data is called the design driver. It was developed on a desktop computer and downloaded to a handheld computer. Time elements are recorded using a keystroke or onscreen button, which stores the operation conducted, and the amount of time required to conduct that operation. Other data collected with the program includes general information about the site (location, weather, etc.), site variables which vary independently of individual time elements (average slope, terrain, etc.), and elemental variables which influence elemental times directly (skidding distance, dbh, etc).

Time studies were being conducted on a large number of yarding systems but Howard (1989) felt that sampling design was being ignored when these studies were conducted. Little thought should be given to the determination of distribution, number of 
observations, and specifications of the desired level of precisions. He developed a sequential approach to sample design for time studies of cable systems, which was a computer based data collection, processing and analysis system. The program can be used to derive confidence intervals on the data collected. This gave an idea of how much more data collection was needed for the data to be statistically viable.

Howard and Therien (1989) developed alternatives to conventional multiple linear regression used to predict yarding costs. When sample sizes are different for two variables in those conventional equations, many observations must be omitted which is a waste of valuable data. In order to make more efficient use of the data, the two alternatives, the sequential estimator and the mixed estimator could be used. The mixed estimator was found to be superior to the sequential estimator and the conventional multiple linear regression for making the best use of the additional observations. They noticed that the use of this method for optimal sampling design of time studies of cable yarding would lead to significant cost savings.

Time studies have been a popular way of investigating productivity of fellerbunchers and other machines on logging operations (Wang and Haarlaa, 2002). Wang et al. (2003) developed a computer based time study system that resides on MS Windows CE. The program is loaded on a handheld computer for data collection in the field. The time study data can then be downloaded to a desktop pc for analysis. A field-tested was conducted collecting the same cycle times for manual felling and cable skidding with a video camera and the computer system. Results indicated differences in elapsed times for elemental times collected by video camera and computer differing by only 0.1 minutes. 
These results showed that the system was a success and it could provide accurate and satisfactory data.

\subsection{Objectives}

The objectives of this research were to:

(1) Conduct a continuous time study on two commonly-used harvesting systems in Central Appalachia: manual felling/cable skidding and feller-buncher felling/grapple skidding,

(2) Estimate the production rates and costs of harvesting machines and systems, and

(3) Compare the two systems in terms of productivity and cost. 


\section{CHAPTER 2 - METHODS AND DATA}

An elemental time study was conducted on two harvesting systems, manual and mechanical, in Northern West Virginia between Spring 2002 and Spring 2003.

\subsection{Machines}

The manual harvesting system consisted of felling with a chainsaw and skidding with a cable skidder. Felling was conducted using a Husqvarna 372 chainsaw and skidding was done using a Timberjack 460 cable skidder (Table 2.1). Specification for each piece of equipment is listed in Table 1.

The mechanical harvesting system consisted of felling using a Timbco 445C Hydro-buncher, top/delimbing using Husqvarna 55 chain saws, and grapple skidding using a Timberjack 460 grapple skidder (Table 2.1). Specifications for these pieces of equipment are listed in Table 1. The feller-buncher used was equipped with a chain and bar type felling head that was not capable of accumulating multiple stems per cycle.

Table 2.1 Equipment specifications.

\begin{tabular}{llllll}
\hline & \multicolumn{2}{c}{ Manual System } & \multicolumn{2}{c}{ Mechanical System } \\
\hline & $\begin{array}{l}\text { Chainsaw } \\
\text { Felling }\end{array}$ & $\begin{array}{l}\text { Cable } \\
\text { Skidding }\end{array}$ & $\begin{array}{l}\text { Feller- } \\
\text { buncher } \\
\text { Felling }\end{array}$ & $\begin{array}{l}\text { Chainsaw } \\
\text { Top/Delimbing }\end{array}$ & $\begin{array}{l}\text { Grapple } \\
\text { Skidding }\end{array}$ \\
\hline Equipment & Husqvarna & Timberjack & Timbco & Husqvarna 55 & Timberjack \\
& 372 & 460 & $445 \mathrm{C}$ & & 460 \\
Horsepower & 5.4 & 174 & 260 & 3.4 & 172 \\
Bar Length & 20 inches & N/A & 33 inches & 18 inches & N/A \\
Boom Reach & N/A & N/A & 14 feet & N/A & N/A \\
\hline
\end{tabular}




\subsection{Sites}

The manual harvesting field study was conducted on site 1 from July to September 2002 on MeadWestvaco timberland near Cassity, WV in Randolph County (Table 2.2). The site contained most hardwood species common to the Appalachian region but was predominantly made up of 6 species: northern red oak (Quercus rubra), black birch (Betula lenta), red maple (Acer rubrum), sugar maple (Acer saccharum), American basswood (Tilia americana), and chestnut oak (Quercus prinus). All other species were grouped together as "Other hardwoods". Diameter at breast height (DBH) of trees harvested ranged from 8 to 26 inches and averaged 15.8 inches. The slope on this site ranged from 10 to $45 \%$ with an average of approximately $25 \%$. The type of harvest on this site was a partial cut.

The mechanized harvesting field study was conducted on 4 sites from Spring 2002 to spring 2003. The feller-buncher field study was conducted from February to April 2002 on sites 2 and 3 in Fellowsville, WV in Preston County and near Clarksburg, WV in Harrison County, respectively (Table 2.2). Major species consisted of: red maple (Acer rubrum), black cherry (Prunus serotina), yellow poplar (Liriodendron tulipifera), black locust (Robina pseudo-acacia), and white ash (Fraxinus Americana). All other species were grouped together as "Other hardwoods". Average DBH of the trees harvested was 16.1 inches and ranged from 7 and 31 inches. Slope on the sites ranges from 0 to $30 \%$ with an average of about $15 \%$. The type of harvest on these sites was a partial cut.

The grapple skidder field study was conducted from October 2002 to February 2003 on sites 4 and 5 on the West Virginia University forest near Morgantown, WV in 
Monongalia County and near Belington, WV in Barbour County, respectively (Table

2.2). Major species for this area were yellow poplar (Liriodendron tulipifera), red maple (Acer rubrum), black cherry (Prunus serotina), northern red oak (Quercus rubra), sugar maple (Acer saccharum). Average DBH was 13.8 inches and ranged from 6 to 27 inches The slope on these sites ranged from 0 to $40 \%$ with an average of approximately $20 \%$. The type of harvest on these sites was a partial cut.

The 5 sites where time study data was collected were slightly different in slope, species composition, and tree size but none of these differences were significant enough to affect productivity.

Table 2.2 Site and stand information.

\begin{tabular}{|c|c|c|c|c|c|}
\hline & Site 1 & Site & Site 3 & Site 4 & Site 5 \\
\hline Harvest & Partial Cut & Partial Cut & Partial Cut & Partial Cut & Partial Cut \\
\hline Type & & & & & \\
\hline $\begin{array}{l}\text { Season of } \\
\text { Harvest }\end{array}$ & Summer 2002 & Summer 2002 & Spring 2002 & Fall 2002 & Spring 2003 \\
\hline Location & $\begin{array}{l}\text { Randolph Co., } \\
\text { WV }\end{array}$ & $\begin{array}{l}\text { Preston Co., } \\
\text { WV }\end{array}$ & $\begin{array}{l}\text { Harrison Co., } \\
\text { WV }\end{array}$ & $\begin{array}{c}\text { Monongalia Co., } \\
\text { WV }\end{array}$ & $\begin{array}{l}\text { Barbour Co. } \\
\text { WV }\end{array}$ \\
\hline Slope & $\begin{array}{l}10-45 \% \\
\text { Avg } \approx 25 \%\end{array}$ & $\begin{array}{l}0-30 \% \\
\text { Avg } \approx 15 \%\end{array}$ & $\begin{array}{l}0-30 \% \\
\text { Avg } \approx 15 \%\end{array}$ & $\begin{array}{l}0-40 \%, \\
\text { Avg } \approx 20 \%\end{array}$ & $\begin{array}{l}0-40 \% \\
\text { Avg } \approx 20 \%\end{array}$ \\
\hline
\end{tabular}

\subsection{Data Collection}

A handheld computer loaded with the Windows CE-based time study data logger was used to measure and record elemental times (Wang et al. 2003). When the handheld computer could not be used, times were measured using a stopwatch and recorded on paper. A work cycle for each operation consisted of certain elemental functions and factors. The times for each function were recorded and the value of each factor was recorded. 


\subsection{Harvesting Functions and Factors}

The functions and factors of each operation were defined as follows:

\subsubsection{Feller-buncher}

Functions:

(1) Drive to tree: Starts when the feller-buncher finishes the previous cycle and begins moving to the next tree to be cut. Ends when movement has stopped and felling is ready to begin.

(2) Cut tree: Begins when the head is positioned on the tree and ends when the tree is completely severed from the stump.

(3) Drive to Dump: Begins when the feller-buncher moves from the stump with the tree and ends when movement is stopped and dump is started.

(4) Dump tree: Begins when tree is tilted by felling head into dump position and ends when tree or tree bunch hits the ground

(5) Bunch: Occurs after tree is dumped but before traveling to next tree to be felled. Consists of time taken to group stems cut into suitable bunch for skidding.

Factors:

(1) Distance to Tree (feet)

(2) Distance to Dump (feet)

(3) Tree Species

(4) $D B H$ (inches)

(5) Merchantable Height (\# of 16-foot logs) 
Since the felling head used on the feller-buncher was not capable of accumulating multiple trees per cycle, only one tree was harvested per cycle. Occasionally, the fellerbuncher would cut two trees without moving anything but the boom. When this occurred, drive to dump for the first tree and drive to tree for the second tree were zero. This rarely occurred due to the partial cut harvest treatment. After felling was complete on the group of trees being observed, men would begin topping/delimbing the trees. This operation ranged from one to three men at a time, but usually consisted of two men. Because of the difficulty in collecting topping and delimbing times for individual trees by each man, total topping/delimbing time was measured for groups of trees and an average time per tree was calculated.

\subsubsection{Chainsaw Felling}

Functions:

(1) Walk to Tree: Begins when feller starts toward the tree to be cut. Ends when feller reaches the tree.

(2) Acquire: Begins when feller starts clearing around tree and judging where tree will fall. Ends when feller is ready to cut tree.

(3) Cut: Begins when feller starts cutting the wedge of the tree. Ends when tree hits the ground.

(4) Top/Delimb: Begins when feller starts delimbing tree. Ends when tree is finished and feller starts toward next tree to cut.

Factors:

(1) Distance to Tree (feet)

(2) Tree Species 
(3) $\mathrm{DBH}$ (inches)

(4) Merchantable Height (\# of 16-foot logs)

There was only one tree being cut per cycle for feller-buncher and chainsaw felling so number of trees per cycle was not a factor. Order and location of felled trees was noted so that species, $\mathrm{DBH}$, and merchantable height of the trees could be recorded when felling was complete.

\subsubsection{Grapple Skidder}

Functions:

(1) Travel Empty: Begins when skidder leaves landing with empty grapple. Ends when skidder arrives at logs to be skidded.

(2) Grapple: Begins when skidder arrives at logs and starts to gather a load. Ends when grapple is full and ready to travel.

(3) Travel Loaded: Begins when skidder starts toward landing with a full grapple of logs. Ends when skidder reaches landing with logs.

(4) Release: Begins when skidder opens grapple and drops logs on landing. Ends when skidder leaves landing for another load.

Factors:

(1) Travel Distance from landing to stump (feet)

(2) Tree Species

(3) $D B H$ (inches)

(4) Merchantable Height (\# of 16-foot logs) 


\subsubsection{Cable Skidding}

Functions:

(1) Travel Empty: Begins when skidder leaves landing with empty cable. Ends when skidder arrives at logs to be skidded.

(2) Choke: Begins when skidder operator gets out to choke logs. Ends when skidder is full and ready to travel.

(3) Travel Loaded: Begins when skidder starts toward lading full of logs. Ends when skidder reaches landing with logs.

(4) Unchoke: Begins when skidder operator gets out to unchoke logs. Ends when skidder leaves landing for another load.

Factors:

(1) Travel Distance from landing to stump (feet)

(2) Tree Species

(3) $D B H$ (inches)

(4) Merchantable Height (\# of 16-foot logs)

\subsection{Data}

The total number of cycles collected for each operation were as follows: 500 for feller-buncher felling and topping/delimbing, 150 for grapple skidding, 300 for chainsaw felling, and 150 for cable skidding (Table 2.3). Due to the amount of time required to collect time study data, the number of observations varied depending on the operation being studied. The feller-buncher had a very short cycle time, which allowed us to collect a very large number of observations. Manual felling had a longer cycle time and fewer observations were collected. Skidding was the slowest and allowed the least 
number of observations. Although the numbers of observations for each operation vary, each is considered to be a large dataset. Large datasets were collected in order to ensure they were statistically viable.

DBH for trees felled mechanically ranged from 7 to 31 inches and averaged 16.1 inches. Trees felled manually ranged in DBH from 6 to 26 inches and averaged 15.8 inches (Table 2.3). DBH for each tree felled manually or mechanically was measured to the nearest inch but was later classed as follows for simplification of data analysis: 6 to 10 in. $=10$ in.; 11 to 15 in. $=15$ in.; 16 to 20 in. $=20$ in.; 21 to 25 in. $=25$ in.; 26 to 31 in. $=30$ in. Merchantable length of each tree felled was measured to the nearest $1 / 2 \log$ or 8 feet. Merchantable height of trees felled mechanically ranged from 8 to 40 feet and averaged 16.9 feet. Manually felled trees ranged in merchantable height from 8 to 56 feet with an average of 29 feet (Table 2.3). Due to the small number of occurrences of trees with a merchantable height over 32 feet for mechanical felling and 48 feet for manual felling, all trees over 32 feet felled mechanically were classed as 32 feet and all trees over 48 feet felled manually were classed as 48 feet to simplify analysis.

Volume for each tree felled manually or mechanically was then calculated. Volume of trees felled manually ranged from 2.7 to $100.2 \mathrm{ft}^{3}$ and averaged $27.4 \mathrm{ft}^{3}$ while volume of trees felled mechanically ranged from 2.7 to $106.6 \mathrm{ft}^{3}$ and averaged $19.1 \mathrm{ft}^{3}$ (Table 2.3).

Each log skidded was measured for DBH to the nearest inch and merchantable height to the nearest $1 / 2 \log$ or 8 feet. Average DBH and merchantable height for logs skid during cable skidding were 14.4 inches and 30.3 feet and ranged from 6 to 24 inches and from 8 to 56 feet, respectively. Average DBH and merchantable height for logs skid 
during grapple skidding were 13.8 inches and 28.1 feet and ranged from 6 to 27 inches and from 8 to 64 feet, respectively (table 2.3). Average DBH and merchantable height for each turn skidded were then calculated. To simplify analysis, those averages were then classed into groups. Average DBH was classed: 10 to 12 in. $=12$ in.; 13 to 14 in. $=$ 14 in.; 15 to 16 in. $=16$ in.; 17 to 18 in. $=18$ in.; 19 to 21 in. $=20$ in. Average merchantable length was classed: $16 \mathrm{ft}$ to $20 \mathrm{ft}=20 \mathrm{ft}$; $21 \mathrm{ft}$ to $25 \mathrm{ft}=25 \mathrm{ft}$; $26 \mathrm{ft}$ to 30 $\mathrm{ft}=30 \mathrm{ft}$; $31 \mathrm{ft}$ to $35 \mathrm{ft}=35 \mathrm{ft} . ; 36 \mathrm{ft}$ to $40 \mathrm{ft}=40 \mathrm{ft}$.; $41 \mathrm{ft}$ to $45 \mathrm{ft}=45 \mathrm{ft}$;

Volume per turn was then calculated for cable skidding and grapple skidding. Volume per turn for cable skidding ranged from 29.2 to $170.7 \mathrm{ft}^{3}$ and averaged $104.2 \mathrm{ft}^{3}$ while volume per turn for grapple skidding ranged from 25.6 to $185.8 \mathrm{ft}^{3}$ and averaged $84.9 \mathrm{ft}^{3}$ (Table 2.3). To simplify analysis, volume per turn was then classed as: $<40 \mathrm{ft}^{3}=$ $40 \mathrm{ft}^{3} ; 41$ to $60 \mathrm{ft}^{3}=60 \mathrm{ft}^{3} ; 61$ to $80 \mathrm{ft}^{3}=80 \mathrm{ft}^{3} ; 81$ to $100 \mathrm{ft}^{3}=100 \mathrm{ft}^{3} ; 101$ to $120 \mathrm{ft}^{3}=$ $120 \mathrm{ft}^{3} ; 121$ to $140 \mathrm{ft}^{3}=140 \mathrm{ft}^{3} ; 141$ to $160 \mathrm{ft}^{3}=160$. There were occurrences of volumes lower than 40 and higher than 160 but they were to few to require a separate class.

Table 2.3 Harvest data.

\begin{tabular}{|c|c|c|c|c|}
\hline & Manual Felling & Cable Skidding & $\begin{array}{l}\text { Mechanized } \\
\text { Felling }\end{array}$ & Grapple Skidding \\
\hline $\begin{array}{l}\text { Number of } \\
\text { Cycles }\end{array}$ & 300 & 150 & 500 & 150 \\
\hline $\begin{array}{l}\text { Avg DBH } \\
\text { (inches) } \\
\text { Avg }\end{array}$ & 15.8 in. per tree & 14.4 in. per turn & 16.1 in. per tree & 13.8 in. per turn \\
\hline $\begin{array}{l}\text { Merchantable } \\
\text { Height (feet) }\end{array}$ & $29.0 \mathrm{ft}$. per tree & $30.3 \mathrm{ft}$. per turn & $16.9 \mathrm{ft}$. per tree & $28.1 \mathrm{ft}$. per turn \\
\hline $\begin{array}{l}\text { Avg Volume } \\
\text { per tree/turn } \\
\left(\mathrm{ft}^{3}\right)\end{array}$ & $\begin{array}{c}27.4 \mathrm{ft}^{3} \\
(164.4 \mathrm{bd} \mathrm{ft}) \\
\text { per tree }\end{array}$ & $\begin{array}{c}104.2 \mathrm{ft}^{3} \\
(625.2 \mathrm{bd} \mathrm{ft}) \\
\text { per turn }\end{array}$ & $\begin{array}{c}19.1 \mathrm{ft}^{3} \\
(114.6 \mathrm{bd} \mathrm{ft}) \\
\text { per tree }\end{array}$ & $\begin{array}{c}84.9 \mathrm{ft}^{3} \\
(509.4 \mathrm{bd} \mathrm{ft}) \\
\text { per turn }\end{array}$ \\
\hline
\end{tabular}


For this research, all volumes were found in cubic feet. An attempt to convert cubic feet to board feet was made to help the readers that are more familiar with that form of measurement. All volumes of board feet stated in this publication are rough estimates and were found using the conversion ratio of $1 \mathrm{ft}^{3}: 6 \mathrm{bd} \mathrm{ft}$ suggested by Avery and Burkhart (2002).

Statistical Analysis Systems (SAS) was used to analyze the data. The general linear model (GLM) procedure was performed on the dataset to determine if any differences of elemental times, cycle time, and hourly productivity existed among operational variables. The general linear model was used because of the difference in observations between operations. 


\section{CHAPTER 3 - DATA ANALYSIS \& RESULTS}

\subsection{Data Analysis}

Data was analyzed using Statistical Analysis Systems (SAS). A GLM model was performed on four datasets, one for each harvesting operation to determine if any differences existed between elemental times, cycle time, and hourly productivity. Four different models were needed to model the four functions.

\section{(1) Chainsaw Felling}

The model used for chainsaw felling is expressed as:

$$
\begin{gathered}
T_{i j k l}=\mu+D_{i}+L_{j}+S_{k}+D_{i} * L_{j}+D_{i} * S_{k}+L_{j} * S_{k}+e_{i j} \\
i=1,2, \ldots 5 \\
j=1,2 \ldots 6 \\
k=1,2 \ldots 7 \\
l=1,2, \ldots, n
\end{gathered}
$$

Where $T_{i j k l}$ represents the $l^{\text {th }}$ observation of the elemental times, cycle times, and hourly production; $\mu$ is the mean of each response variable; $D_{i}$ is the effect of the ${ }_{\mathrm{i}}$ th $\mathrm{DBH} ; L_{j}$ is the effect of the ${ }_{\mathrm{j}}$ th merchantable length; $S_{k}$ is the effect of the ${ }_{\mathrm{k}}$ th Species; $\mathrm{e}_{\mathrm{ij}}$ is an error component that represents uncontrolled variability; and $n$ is the number of observations within each treatment. Interactions among $\mathrm{DBH}$, merchantable length, and species were also considered in the model. Regression techniques were used to produce prediction equations for elemental times, hourly productivity, and unit cost. 
(2) Cable Skidding

The model used for cable skidding is expressed as:

$$
\begin{gathered}
T_{i j k l m n}=\mu+A D_{i}+A L_{j}+N L_{k}+T V_{l}+S D_{m}+A D_{i} * A L_{j}+A D_{i} * S D_{m}+A L j * S D_{m}+T V_{l} * \\
S D_{m}+N L_{k} * S D_{m}+e_{i j} \\
i=1,2, \ldots 5 \\
j=1,2 \ldots 6 \\
k=1,2,3,4 \\
l=1,2, \ldots 6 \\
m=1,2 \ldots 6 \\
n=1,2, \ldots, o
\end{gathered}
$$

Where $T_{i j k l m n}$ represents the $n^{\text {th }}$ observation of the elemental times, cycle times, and hourly production; $\mu$ is the mean of each response variable; $A D_{i}$ is the effect of the ith average DBH per turn; $A L_{j}$ is the effect of the ${ }_{j}$ th average merchantable length per turn; $N L_{k}$ is the effect of the ${ }_{\mathrm{k}}$ th number of logs per turn; $T V_{l}$ is the effect of the $l$ th total volume per turn; $S D_{m}$ is the effect of the $m$ th skidding distance; $\mathrm{e}_{\mathrm{ij}}$ is an error component that represents uncontrolled variability; and $o$ is the number of observations within each treatment. Interactions among average $\mathrm{DBH}$, average merchantable length, number of logs, total volume, and skidding distance were also considered in the model. Regression techniques were used to produce prediction equations for elemental times, hourly productivity, and unit cost. 
(3) Feller-buncher Felling

The model used for feller-buncher felling is expressed as:

$$
\begin{gathered}
T_{i j k l}=\mu+D_{i}+L_{j}+S_{k}+D_{i} * L_{j}+D_{i} * S_{k}+L_{j} * S_{k}+e_{i j} \\
i=1,2, \ldots 5 \\
j=1,2 \ldots 4 \\
k=1,2 \ldots 6 \\
l=1,2, \ldots, n
\end{gathered}
$$

Where $T_{i j k l}$ represents the $l^{\text {th }}$ observation of the elemental times, cycle times, and hourly production; $\mu$ is the mean of each response variable; $D_{i}$ is the effect of the ${ }_{\mathrm{i}}$ th $\mathrm{DBH} ; L_{j}$ is the effect of the ${ }_{\mathrm{j}}$ th merchantable length; $S_{k}$ is the effect of the ${ }_{\mathrm{k}}$ th Species; $\mathrm{e}_{\mathrm{ij}}$ is an error component that represents uncontrolled variability; and $n$ is the number of observations within each treatment. Interactions among DBH, merchantable length, and species were also considered in the model. Regression techniques were used to produce prediction equations for elemental times, hourly productivity, and unit cost. 


\section{(4) Grapple Skidding}

The model used for grapple skidding is expressed as:

$$
\begin{gathered}
T_{i j k l m n}=\mu+A D_{i}+A L_{j}+N L_{k}+T V_{l}+S D_{m}+A D_{i} * A L_{j}+A D_{i} * S D_{m}+A L j * S D_{m}+T V_{l} * \\
S D_{m}+N L_{k} * S D_{m}+e_{i j} \\
i=1,2, \ldots 5 \\
j=1,2 \ldots 6 \\
k=1,2, \ldots 5 \\
l=1,2, \ldots 7 \\
m=1,2,3,4 \\
n=1,2, \ldots, o
\end{gathered}
$$

Where $T_{i j k l m n}$ represents the $n^{\text {th }}$ observation of the elemental times, cycle times, and hourly production; $\mu$ is the mean of each response variable; $A D_{i}$ is the effect of the ith average DBH per turn; $A L_{j}$ is the effect of the ${ }_{j}$ th average merchantable length per turn; $N L_{k}$ is the effect of the ${ }_{\mathrm{k}}$ th number of logs per turn; $T V_{l}$ is the effect of the $l$ th total volume per turn; $S D_{m}$ is the effect of the $m$ th skidding distance; $\mathrm{e}_{\mathrm{ij}}$ is an error component that represents uncontrolled variability; and $o$ is the number of observations within each treatment. Interactions among average $\mathrm{DBH}$, average merchantable length, number of logs, total volume, and skidding distance were also considered in the model. Regression techniques were used to produce prediction equations for elemental times, hourly productivity, and unit cost. 


\subsection{Results}

\subsubsection{Productivities of Harvesting Machines}

\subsubsection{Chainsaw Felling}

$\underline{\text { Elemental Times }}$

Total felling time - Adding all productive elements of felling including walk to tree, acquire, cut, and top/delimb for each tree gives us a total felling time for each individual tree. Mean total felling time did not differ significantly among species $(F=1.90 ; \mathrm{df}=6$, $288 ; \mathrm{P}=.0810$ ) and ranged from 3.01 to 5.48 minutes. Total felling time did differ significantly among $\mathrm{DBH}$ class $(\mathrm{F}=41.52 ; \mathrm{df}=4,288 ; \mathrm{P}=.0001)$ and merchantable length $(\mathrm{F}=4.20 ; \mathrm{df}=5,288 ; \mathrm{P}=.0011)$ with ranges of 2.13 to 9.85 minutes, and 2.61 to 9.65 minutes respectively (Table 3.1). A regression model was developed to estimate total felling time per tree (Table 3.2). Total felling time was best described by DBH and distance to tree.

Walk to tree - There was no significant differences in walk to tree time among species $(\mathrm{F}=1.32 ; \mathrm{df}=6,288 ; \mathrm{P}=.2507)$ with a range of .19 to .37 minutes, merchantable length $(\mathrm{F}=1.10 ; \mathrm{df}=5,288 ; \mathrm{P}=.3630)$ with a range of .23 to .43 minutes, or DBH classes $(\mathrm{F}=1.92 ; \mathrm{df}=4,288 ; \mathrm{P}=.1077)$ with a range of .17 to .43 minutes (Table 3.1$)$.

Acquire - No significant differences in mean acquire time were found among species ( $\mathrm{F}=$ $0.20 ; \mathrm{df}=6,288 ; \mathrm{P}=.9761)$ with times ranging from .29 to .59 minutes, DBH classes $(\mathrm{F}=1.96 ; \mathrm{df}=4,288 ; \mathrm{P}=.1020)$ with times ranging from .1 to .53 minutes, or 
merchantable length $(\mathrm{F}=.58 ; \mathrm{df}=5,288 ; \mathrm{P}=.7160)$ with a range of .22 to .56 minutes (Table 3.1).

Cut - Time to cut a tree was not significantly different among species $(\mathrm{F}=1.92 ; \mathrm{df}=6$, $288 ; \mathrm{P}=.0793$ ) with means ranging from 1.08 to 1.98 minutes. Cut time was significantly different among $\mathrm{DBH}(\mathrm{F}=64.25 ; \mathrm{df}=4,288 ; \mathrm{P}=.0001)$ ranging from 1.10 to 4.25 minutes and merchantable length $(\mathrm{F}=4.42 ; \mathrm{df}=5,288 ; \mathrm{P}=.0007)$ ranging from .73 to 2.49 minutes (Table 3.1). A model developed using regression analysis allows estimation of cut time per tree (Table 3.2). It was found that cut time was affected by DBH.

Top/delimb - Top/delimb time did not significantly differ among species $(\mathrm{F}=2.11 ; \mathrm{df}=6$, $288 ; \mathrm{P}=.0527$ ) with mean times ranging from 1.52 to 2.69 minutes. Top/delimb times did differ significantly among $\mathrm{DBH}$ classes $(\mathrm{F}=24.48 ; \mathrm{df}=4,288 ; \mathrm{P}=.0001)$ and merchantable length $(\mathrm{F}=3.15 ; \mathrm{df}=5,288 ; \mathrm{P}=.0090)$ with mean times ranging from 1.08 to 5.25 minutes, and from 1.43 to 3.47 minutes, respectively (Table 3.1). Regression analysis was conducted to produce a prediction equation for top/delimb time (Table 3.2). DBH was found to best predict top/delimb time.

Delay - Manual felling delay was only observed 54 times during the study. Delay was usually due to maintenance of the saw and included filling it with gas and oil and sharpening the chain when dull. Manual felling delay was not significantly different among species $(\mathrm{F}=0.81 ; \mathrm{df}=6,288 ; \mathrm{P}=.5663), \mathrm{DBH}$ classes $(\mathrm{F}=1.04 ; \mathrm{df}=4,288 ; \mathrm{P}=$ 
$.3850)$, or merchantable length $(\mathrm{F}=1.81 ; \mathrm{df}=5,288 ; \mathrm{P}=.1127)$ with ranges of .34 to 3.00 minutes, 1.04 to 3.73 minutes, and .50 to 3.52 minutes, respectively (Table 3.1).

\section{$\underline{\text { Productivity }}$}

Observed productivity of manual felling was significantly different among species $(\mathrm{F}=2.29 ; \mathrm{df}=6,288 ; \mathrm{P}=.0361), \mathrm{DBH}(\mathrm{F}=59.62 ; \mathrm{df}=4,288 ; \mathrm{P}=.0001)$, and merchantable length $(\mathrm{F}=21.08 ; \mathrm{df}=5,288 ; \mathrm{P}=.0001)$ with ranges of 291.06 to 476.86 $\mathrm{ft}^{3} / \mathrm{PMH}$ (1746.36 to $2861.16 \mathrm{bd} \mathrm{ft/PMH),} 138.76 \mathrm{ft}^{3}$ to $610.24 \mathrm{ft}^{3} / \mathrm{PMH}$ (832.56 to $3661.44 \mathrm{bd} \mathrm{ft} / \mathrm{PMH}$ ), and $113.74 \mathrm{ft}^{3}$ to $535.43 \mathrm{ft} 3 / \mathrm{PMH}$ (682.44 to $3212.58 \mathrm{bd} \mathrm{ft} / \mathrm{PMH}$ ) respectively (Table 3.1). A regression model was developed to estimate the productivity of the feller-buncher (Table 3.2). Factors that affect felling productivity are DBH, merchantable length, and distance between harvested trees. 
Table 3.1 - Means and significance levels of statistics for the manual felling during time and motion studies. ${ }^{\text {a }}$

\begin{tabular}{|c|c|c|c|c|c|c|c|}
\hline & \multicolumn{6}{|c|}{ Elemental Times (min) } & \multirow{2}{*}{$\begin{array}{l}\begin{array}{c}\text { Average Production } \\
\left(\mathbf{f t}^{\mathbf{3}} / \mathbf{P M H}\right)\end{array} \\
\text { Felling Productivity }\end{array}$} \\
\hline & $\begin{array}{c}\text { Total Felling } \\
\text { Time }\end{array}$ & $\begin{array}{c}\text { Walk to } \\
\text { Tree }\end{array}$ & Acquire & Cut & $\begin{array}{c}\text { Top/ } \\
\text { Delimb }\end{array}$ & Delay & \\
\hline \multicolumn{8}{|l|}{ Species } \\
\hline Basswood & $3.01 \mathrm{~A}$ & $0.19 \mathrm{~A}$ & $0.30 \mathrm{~A}$ & $1.08 \mathrm{~A}$ & $1.52 \mathrm{~A}$ & $0.34 \mathrm{~A}$ & $393.03 \mathrm{BC}$ \\
\hline Red Maple & $3.70 \mathrm{~A}$ & $0.34 \mathrm{~B}$ & $0.29 \mathrm{~A}$ & $1.20 \mathrm{AB}$ & $1.86 \mathrm{ABC}$ & $0.88 \mathrm{~A}$ & $291.06 \mathrm{~A}$ \\
\hline Birch & $3.80 \mathrm{AB}$ & $0.28 \mathrm{AB}$ & $0.35 \mathrm{~A}$ & $1.44 \mathrm{BC}$ & $1.73 \mathrm{AB}$ & $1.23 \mathrm{~A}$ & $304.11 \mathrm{~A}$ \\
\hline Sugar Maple & $4.73 \mathrm{C}$ & $0.37 \mathrm{~B}$ & $0.44 \mathrm{~A}$ & $1.68 \mathrm{CD}$ & $2.24 \mathrm{BCD}$ & $0.37 \mathrm{~A}$ & $372.06 \mathrm{BC}$ \\
\hline Chestnut Oak & $5.12 \mathrm{C}$ & $0.32 \mathrm{AB}$ & $0.59 \mathrm{~A}$ & $1.66 \mathrm{C}$ & $2.55 \mathrm{D}$ & $0.75 \mathrm{~A}$ & $476.86 \mathrm{D}$ \\
\hline Red Oak & $5.48 \mathrm{C}$ & $0.34 \mathrm{~B}$ & $0.47 \mathrm{~A}$ & $1.98 \mathrm{D}$ & $2.69 \mathrm{D}$ & $3.00 \mathrm{~A}$ & $422.81 \mathrm{CD}$ \\
\hline Other & $4.65 \mathrm{BC}$ & $0.37 \mathrm{~B}$ & $0.40 \mathrm{~A}$ & $1.47 \mathrm{BC}$ & $2.42 \mathrm{CD}$ & $1.58 \mathrm{~A}$ & $353.27 \mathrm{AB}$ \\
\hline \multicolumn{8}{|l|}{ DBH (in) } \\
\hline 10 & $2.13 \mathrm{~A}$ & $0.17 \mathrm{~A}$ & $0.18 \mathrm{~A}$ & $0.70 \mathrm{~A}$ & $1.08 \mathrm{~A}$ & $1.92 \mathrm{~A}$ & $138.76 \mathrm{~A}$ \\
\hline 15 & $3.41 \mathrm{AB}$ & $0.32 \mathrm{~A}$ & $0.31 \mathrm{~A}$ & $1.10 \mathrm{~A}$ & $1.68 \mathrm{AB}$ & $1.04 \mathrm{~A}$ & $268.78 \mathrm{~A}$ \\
\hline 20 & $5.44 \mathrm{BC}$ & $0.33 \mathrm{~A}$ & $0.50 \mathrm{~A}$ & $1.92 \mathrm{~B}$ & $2.69 \mathrm{~B}$ & $1.64 \mathrm{~A}$ & $441.42 \mathrm{~B}$ \\
\hline 25 & $6.75 \mathrm{C}$ & $0.43 \mathrm{~A}$ & $0.53 \mathrm{~A}$ & $2.68 \mathrm{~B}$ & $3.11 \mathrm{~B}$ & $3.73 \mathrm{~A}$ & $593.11 \mathrm{~B}$ \\
\hline 30 & $9.85 \mathrm{D}$ & $0.25 \mathrm{~A}$ & $0.1 \mathrm{~A}$ & $4.25 \mathrm{C}$ & $5.25 \mathrm{C}$ & $1.60 \mathrm{~A}$ & 610.24 B \\
\hline \multicolumn{8}{|l|}{ Length (ft) } \\
\hline 8 & $2.61 \mathrm{~A}$ & $0.23 \mathrm{~A}$ & $0.22 \mathrm{~A}$ & $0.73 \mathrm{~A}$ & $1.43 \mathrm{~A}$ & $1.30 \mathrm{~A}$ & $113.74 \mathrm{~A}$ \\
\hline 16 & $3.08 \mathrm{~A}$ & $0.29 \mathrm{~A}$ & $0.28 \mathrm{~A}$ & $0.97 \mathrm{~A}$ & $1.54 \mathrm{AB}$ & $1.59 \mathrm{~A}$ & $208.12 \mathrm{~B}$ \\
\hline 24 & $4.08 \mathrm{~B}$ & $0.30 \mathrm{AB}$ & $0.31 \mathrm{~A}$ & $1.50 \mathrm{~B}$ & $1.96 \mathrm{BC}$ & $0.98 \mathrm{~A}$ & $297.35 \mathrm{C}$ \\
\hline 32 & $4.86 \mathrm{BC}$ & $0.32 \mathrm{AB}$ & $0.45 \mathrm{~A}$ & $1.64 \mathrm{~B}$ & $2.39 \mathrm{CD}$ & $0.78 \mathrm{~A}$ & 406.39 D \\
\hline 40 & $5.27 \mathrm{C}$ & $0.36 \mathrm{AB}$ & $0.51 \mathrm{~A}$ & $1.93 \mathrm{C}$ & $2.52 \mathrm{D}$ & $3.52 \mathrm{~A}$ & $520.35 \mathrm{E}$ \\
\hline 48 & $9.65 \mathrm{D}$ & $0.43 \mathrm{~B}$ & $0.56 \mathrm{~A}$ & $2.49 \mathrm{D}$ & $3.47 \mathrm{E}$ & $0.50 \mathrm{~A}$ & $535.43 \mathrm{E}$ \\
\hline
\end{tabular}

${ }^{a}$ Means with the same capital letter in a column are not significantly different at the 5 percent level with Duncan's Multiple-Range Test.

Table 3.2. Models to estimate manual felling times and productivities.

\begin{tabular}{|c|c|c|c|c|c|}
\hline & Models $^{\text {a }}$ & $\overline{\mathrm{R}^{2}}$ & RMSE & P-value & F - value \\
\hline Cut time per tree $(\mathrm{min})$ & $0.1165+.00555 \mathrm{DBH}^{2}$ & 0.52 & 0.57 & 0.0001 & 315.77 \\
\hline Top/Delimb time per tree (min) & $-1.1457+.2117 \mathrm{DBH}$ & 0.32 & 1.01 & 0.0001 & 132.88 \\
\hline Total time per tree (min) & $-2.4295+0.4222 \mathrm{DBH}+0.0002 \mathrm{Dist}^{2}$ & 0.47 & 1.55 & 0.0001 & 128.89 \\
\hline Total productivity (ft 3/PMH) & $\begin{array}{l}\text { 72.7178+0.8810DBH*L-0.0003DBH }{ }^{2 *} \mathrm{~L}^{2}- \\
\text { 1.4087DistT }\end{array}$ & 0.56 & 121.3 & 0.0001 & 122.43 \\
\hline
\end{tabular}

${ }^{\mathrm{a}} \mathrm{DBH}=$ diameter at breast height (in); $\mathrm{L}=$ merchantable length (ft); Dist T = distance to tree (ft);

RMSE $=$ root of mean square error 


\subsubsection{Cable Skidding}

\section{$\underline{\text { Elemental Times }}$}

Total skidding time - All productive elements of skidding time including travel empty, choke, travel loaded, and unchoke for each turn gives us a total skidding time for each turn. Mean total skidding times differed significantly among average DBH per turn $(\mathrm{F}=19.57 ; \mathrm{df}=4,139 ; \mathrm{P}=.0001)$, average merchantable lengths per turn $(\mathrm{F}=4.70 ; \mathrm{df}=$ $5,139 ; \mathrm{P}=.0015)$, number of $\operatorname{logs}$ per turn $(\mathrm{F}=8.26 ; \mathrm{df}=3,139 ; \mathrm{P}=.0002)$, payload per turn $(\mathrm{F}=3.86 ; \mathrm{df}=5,139 ; \mathrm{P}=.0052)$, and skidding distance $(\mathrm{F}=20.39 ; \mathrm{df}=5,139 ; \mathrm{P}=$ .0001 ) with ranges of 19.91 to 25.34 minutes, 18.12 to 24.40 minutes, 21.14 to 22.87 minutes, 17.35 to 24.72 minutes, and 18.14 to 25.01 minutes, respectively (Table 3.3). Significant differences were also found in total skidding time among interactions between average diameter and average length, average diameter and skidding distance, average length and skidding distance, and number of logs and skidding distance. A regression model was developed to estimate total skidding time (Table 3.4). Total skidding time was best described by skidding distance and payload per turn.

Travel empty - Mean travel empty time ranged from 3.40 to 7.59 minutes and showed a significant difference among skidding distance $(\mathrm{F}=120.46 ; \mathrm{df}=5,139 ; \mathrm{P}=.0001)$ (Table 3.3). A model developed using regression analysis allows estimation of travel empty time (Table 3.4). It was found that travel empty time was solely affected by skidding distance. 
Choke - Mean choke time did not differ significantly among DBH classes $(\mathrm{F}=1.18$; $\mathrm{df}=$ $4,139 ; \mathrm{P}=.3331)$ and ranged from .5 .09 to 5.79 minutes, however, mean time taken to choke each group of logs was significantly different among merchantable length $(\mathrm{F}=$ $5.85 ; \mathrm{df}=5,139 ; \mathrm{P}=.0003)$, number of $\operatorname{logs}(\mathrm{F}=8.05 ; \mathrm{df}=3,139 ; \mathrm{P}=.0002)$, and total payload $(\mathrm{F}=3.28 ; \mathrm{df}=5,139 ; \mathrm{P}=.0127)$ with ranges of 4.15 to 5.87 minutes, 4.81 to 6.22 minutes, and 4.97 to 5.81 minutes, respectively (Table 3.3). A significant difference in choke time was also found among the interaction between average diameter and length.

Travel Loaded - There were significant differences in travel loaded times among DBH classes $(\mathrm{F}=67.80 ; \mathrm{df}=4,139 ; \mathrm{P}=.0001)$, merchantable lengths $(\mathrm{F}=38.65 ; \mathrm{df}=5,139 ; \mathrm{P}$ $=.0001)$, number of $\operatorname{logs}(\mathrm{F}=21.28 ; \mathrm{df}=3,139 ; \mathrm{P}=.0001)$, total payload $(\mathrm{F}=15.71 ; \mathrm{df}=$ $5,139 ; \mathrm{P}=.0001)$, and skidding distance $(\mathrm{F}=53.90 ; \mathrm{df}=5,139 ; \mathrm{P}=.0001)$ with times ranging from 6.53 to 9.63 minutes, 6.16 to 8.87 minutes, 7.54 to 7.83 minutes, 5.31 to 9.57 minutes, and 5.32 to 9.30 minutes, respectively (Table 3.3). Significant differences were also found in travel loaded time among interactions between average diameter and average length, average diameter and skidding distance, average length and skidding distance, total volume and skidding distance, and number of logs and skidding distance. A model developed using regression analysis allows estimation of travel loaded time (Table 3.4). It was found that travel loaded time was sensitive to skidding distance and turn payload. 
Unchoke - Unchoke time was found to be significantly affected by $\mathrm{DBH}(\mathrm{F}=3.01 ; \mathrm{df}=4$, $139 ; \mathrm{P}=.0271)$ ranging from 2.44 to 3.29 minutes, merchantable length $(\mathrm{F}=2.98 ; \mathrm{df}=5$, $139 ; \mathrm{P}=.0203)$ ranging from 2.75 to 3.39 minutes, and number of $\operatorname{logs}(\mathrm{F}=8.17 ; \mathrm{df}=3$, $139 ; \mathrm{P}=.0002$ ) ranging from 2.73 to 3.85 minutes. Unchoke time did not significantly differ among total payload classes $(\mathrm{F}=1.43 ; \mathrm{df}=5,139 ; \mathrm{P}=.2192)$ ranging from 2.86 to 3.30 minutes (Table 3.3). There was also a significant difference in unchoke time among the interaction between average diameter and average length.

Delay - Cable skidding delay was only observed 24 times during the study. Delay was usually due to maintenance of the skidder and fixing broken cable. Delay of the cable skidder was significantly different among DBH classes $(\mathrm{F}=8.52 ; \mathrm{df}=4,139 ; \mathrm{P}=.0001)$, average length $(\mathrm{F}=20.29 ; \mathrm{df}=5,139 ; \mathrm{P}=.0001)$, number of $\operatorname{logs}(\mathrm{F}=7.37 ; \mathrm{df}=3,139 ; \mathrm{P}$ $=.0004)$, and skidding distance $(\mathrm{F}=8,93 ; \mathrm{df}=5,139 ; \mathrm{P}=.0001)$ with ranges of 0 to 1.67 minutes, 0 to 2.77 minutes, 0.1 to 1.15 minutes, and 0 to 1.55 minutes, respectively. Delay did not differ significantly among total volume per turn $(\mathrm{F}=1.52 ; \mathrm{df}=5,139 ; \mathrm{P}=$ .2027) with a range from 0.27 to 0.99 minutes (Table 3.3). Significant differences were also found in travel loaded time among interactions between average diameter and average length, average diameter and skidding distance, average length and skidding distance, total volume and skidding distance, and number of logs and skidding distance.

\section{Productivity}

Observed productivity of cable skidding was significantly different among DBH classes $(\mathrm{F}=27.40 ; \mathrm{df}=4,139 ; \mathrm{P}=.0001)$, merchantable length $(\mathrm{F}=33.63 ; \mathrm{df}=5,139 ; \mathrm{P}$ 
$=.0001)$, number of $\operatorname{logs}(\mathrm{F}=31.16 ; \mathrm{df}=3,139 ; \mathrm{P}=.0001)$, total payload $(\mathrm{F}=7.69 ; \mathrm{df}=$ $5,139 ; \mathrm{P}=.0001)$, and skidding distance $(\mathrm{F}=13.40 ; \mathrm{df}=5,139 ; \mathrm{P}=.0001)$ with ranges of 235.66 to $332.15 \mathrm{ft} 3 / \mathrm{PMH}$ (1413.96 to $1992.9 \mathrm{bd} \mathrm{ft} / \mathrm{PMH}$ ), 194.69 to $332.91 \mathrm{ft} 3 / \mathrm{PMH}$ (1168.14 to $1997.46 \mathrm{bd} \mathrm{ft/PMH),} 267.63$ to $323.61 \mathrm{ft} / \mathrm{PMH}$ (1605.78 to $1941.66 \mathrm{bd}$

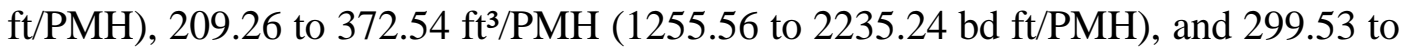
$306.09 \mathrm{ft}$ 3/PMH (1797.18 to $1836.54 \mathrm{bd} \mathrm{ft/PMH)} \mathrm{respectively} \mathrm{(Table} \mathrm{3.3).} \mathrm{Significant}$ differences were also found in productivity among the interactions between average diameter and average length, average diameter and skidding distance, and number of logs per turn and skidding distance. A regression model was also developed to estimate the productivity of the cable skidding (Table 3.4). Factors that affect cable skidding productivity are skidding distance and total volume of the skid. 
Table 3.3 - Means and significance levels of statistics for cable skidding during time and motion studies. ${ }^{\text {a }}$

\begin{tabular}{|c|c|c|c|c|c|c|c|}
\hline & \multicolumn{6}{|c|}{ Elemental Times (min) } & \multirow{2}{*}{$\begin{array}{c}\begin{array}{c}\text { Average Production } \\
\left(\mathbf{f t}^{3} / \mathbf{P M H}\right)\end{array} \\
\text { Skidding } \\
\text { Productivity } \\
\end{array}$} \\
\hline & $\begin{array}{c}\text { Total Skidding } \\
\text { Time }\end{array}$ & $\begin{array}{l}\text { Travel } \\
\text { Empty }\end{array}$ & Choke & $\begin{array}{r}\text { Travel } \\
\text { Loaded } \\
\end{array}$ & Unchoke & Delay & \\
\hline \multicolumn{8}{|c|}{ Average } \\
\hline \multicolumn{8}{|c|}{ DBH (in) } \\
\hline 12 & $19.91 \mathrm{~A}$ & N/A & $5.79 \mathrm{~A}$ & $6.53 \mathrm{~A}$ & $3.13 \mathrm{~A}$ & $1.67 \mathrm{~A}$ & $235.66 \mathrm{~A}$ \\
\hline 14 & $20.86 \mathrm{~A}$ & N/A & $5.31 \mathrm{~A}$ & $6.95 \mathrm{~A}$ & $3.29 \mathrm{~A}$ & $0.76 \mathrm{AB}$ & $265.49 \mathrm{AB}$ \\
\hline 16 & $21.20 \mathrm{~A}$ & N/A & $5.09 \mathrm{~A}$ & $7.42 \mathrm{~A}$ & $3.13 \mathrm{~A}$ & $0.59 \mathrm{AB}$ & 305.46 BC \\
\hline 18 & $23.91 \mathrm{~B}$ & N/A & $5.49 \mathrm{~A}$ & $8.57 \mathrm{~B}$ & $3.19 \mathrm{~A}$ & $0.29 \mathrm{~B}$ & $326.29 \mathrm{C}$ \\
\hline 20 & $25.34 \mathrm{~B}$ & N/A & $5.55 \mathrm{~A}$ & $9.63 \mathrm{C}$ & $2.44 \mathrm{~B}$ & $0.00 \mathrm{~B}$ & $332.15 \mathrm{C}$ \\
\hline \multicolumn{8}{|c|}{ Average } \\
\hline \multicolumn{8}{|c|}{ Length (ft) } \\
\hline 20 & $18.12 \mathrm{~A}$ & N/A & $4.15 \mathrm{~A}$ & $6.17 \mathrm{~A}$ & $3.07 \mathrm{~A}$ & $0.00 \mathrm{~A}$ & $194.69 \mathrm{~A}$ \\
\hline 25 & $20.61 \mathrm{~B}$ & N/A & $5.87 \mathrm{C}$ & $6.16 \mathrm{~A}$ & $3.28 \mathrm{~A}$ & $0.63 \mathrm{~A}$ & $224.30 \mathrm{~A}$ \\
\hline 30 & $21.53 \mathrm{~B}$ & N/A & $5.66 \mathrm{BC}$ & $7.18 \mathrm{AB}$ & $3.25 \mathrm{~A}$ & $0.83 \mathrm{~A}$ & $280.10 \mathrm{~B}$ \\
\hline 35 & $21.77 \mathrm{~B}$ & N/A & $5.02 \mathrm{ABC}$ & $7.90 \mathrm{BC}$ & $3.05 \mathrm{~A}$ & $0.35 \mathrm{~A}$ & $317.27 \mathrm{BC}$ \\
\hline 40 & $24.40 \mathrm{C}$ & N/A & $5.62 \mathrm{BC}$ & $8.55 \mathrm{C}$ & $3.39 \mathrm{~A}$ & $0.00 \mathrm{~A}$ & $327.63 \mathrm{C}$ \\
\hline 45 & $21.98 \mathrm{~B}$ & N/A & $4.47 \mathrm{AB}$ & $8.87 \mathrm{C}$ & $2.75 \mathrm{~A}$ & $2.77 \mathrm{~B}$ & $332.91 \mathrm{C}$ \\
\hline \multicolumn{8}{|c|}{ Number of Logs } \\
\hline 3 & $21.62 \mathrm{~A}$ & N/A & $4.81 \mathrm{~A}$ & $7.54 \mathrm{AB}$ & $2.73 \mathrm{~A}$ & $0.10 \mathrm{~A}$ & $267.63 \mathrm{~A}$ \\
\hline 4 & $21.94 \mathrm{AB}$ & N/A & $5.13 \mathrm{AB}$ & $7.66 \mathrm{~B}$ & $3.09 \mathrm{~B}$ & $0.53 \mathrm{~A}$ & $272.52 \mathrm{~A}$ \\
\hline 5 & $21.14 \mathrm{~A}$ & N/A & $5.47 \mathrm{~B}$ & $7.24 \mathrm{~A}$ & $3.15 \mathrm{~B}$ & $1.15 \mathrm{~B}$ & $303.17 \mathrm{~B}$ \\
\hline 6 & $22.87 \mathrm{~B}$ & N/A & $6.22 \mathrm{C}$ & $7.83 \mathrm{~B}$ & $3.85 \mathrm{C}$ & $0.33 \mathrm{~A}$ & $323.61 \mathrm{C}$ \\
\hline \multicolumn{8}{|c|}{ Total Volume $\mathrm{ft}^{3}$} \\
\hline 60 & $17.35 \mathrm{~A}$ & N/A & $4.97 \mathrm{~A}$ & $5.31 \mathrm{~A}$ & $2.86 \mathrm{~A}$ & $0.74 \mathrm{AB}$ & $209.26 \mathrm{~A}$ \\
\hline 80 & $20.43 \mathrm{~B}$ & N/A & $5.58 \mathrm{AB}$ & $6.45 \mathrm{~B}$ & $3.16 \mathrm{AB}$ & $0.58 \mathrm{AB}$ & $212.92 \mathrm{~A}$ \\
\hline 100 & $21.02 \mathrm{~B}$ & N/A & $5.51 \mathrm{AB}$ & $7.03 \mathrm{C}$ & $3.30 \mathrm{~B}$ & $0.99 \mathrm{~B}$ & $269.84 \mathrm{~B}$ \\
\hline 120 & $22.37 \mathrm{C}$ & N/A & $5.28 \mathrm{AB}$ & $7.92 \mathrm{D}$ & $3.10 \mathrm{AB}$ & $0.84 \mathrm{~B}$ & $302.66 \mathrm{C}$ \\
\hline 140 & $22.91 \mathrm{C}$ & N/A & $5.81 \mathrm{~B}$ & $8.13 \mathrm{D}$ & $3.17 \mathrm{AB}$ & $0.27 \mathrm{~A}$ & $347.25 \mathrm{D}$ \\
\hline 160 & $24.72 \mathrm{D}$ & N/A & $5.27 \mathrm{AB}$ & $9.57 \mathrm{E}$ & $3.22 \mathrm{AB}$ & $0.43 \mathrm{AB}$ & $372.54 \mathrm{E}$ \\
\hline \multicolumn{8}{|c|}{ Skidding Distance (ft) } \\
\hline 1500 & $18.14 \mathrm{~A}$ & $3.40 \mathrm{~A}$ & N/A & $5.32 \mathrm{~A}$ & N/A & $1.48 \mathrm{~A}$ & $299.53 \mathrm{AB}$ \\
\hline 2000 & $20.93 \mathrm{BC}$ & $5.25 \mathrm{C}$ & N/A & $7.20 \mathrm{C}$ & N/A & $0.51 \mathrm{~B}$ & 277.87 BC \\
\hline 2500 & $20.38 \mathrm{~B}$ & $4.75 \mathrm{~B}$ & N/A & $6.81 \mathrm{~B}$ & N/A & $0.72 \mathrm{~B}$ & $291.80 \mathrm{AB}$ \\
\hline 3000 & $21.69 \mathrm{C}$ & $5.86 \mathrm{D}$ & N/A & $7.91 \mathrm{D}$ & N/A & $1.55 \mathrm{~A}$ & $306.20 \mathrm{~A}$ \\
\hline 3500 & $23.75 \mathrm{D}$ & $7.01 \mathrm{E}$ & N/A & $8.33 \mathrm{E}$ & N/A & $0 \mathrm{C}$ & $265.51 \mathrm{C}$ \\
\hline 4000 & $25.01 \mathrm{E}$ & $7.59 \mathrm{~F}$ & N/A & $9.30 \mathrm{~F}$ & N/A & $0 \mathrm{C}$ & $306.09 \mathrm{~A}$ \\
\hline
\end{tabular}

${ }^{a}$ Means with the same capital letter in a column are not significantly different at the 5 percent level with

Duncan's Multiple-Range Test. 
Table 3.4 - Models to estimate cable skidding times and productivities.

\begin{tabular}{|c|c|c|c|c|c|}
\hline & Models a & $\mathrm{R}^{2}$ & RMSE & P-value & $\mathrm{F}$ - value \\
\hline Travel empty (min) & $0.8461+0.0025$ Dist-0.0000002 Dist $^{2}$ & 0.74 & 0.84 & 0.0001 & 191.03 \\
\hline Travel loaded (min) & $\begin{array}{l}\text { 0.5278+0.0027Dist-0.0000003Dist }{ }^{2}+ \\
\text { 0.0256TotVol }\end{array}$ & 0.64 & 1.11 & 0.0001 & 81.92 \\
\hline Total time per turn (min) & $\begin{array}{l}\text { 9.9180+0.0049Dist- } \\
\text { 0.0000006 } \text { Dist }^{2}+0.0338 \text { TotVol }\end{array}$ & 0.49 & 2.69 & 0.0001 & 42.74 \\
\hline Skidding productivity $\left(\mathrm{ft}^{3} / \mathrm{PMH}\right)$ & $\begin{array}{l}\text { 196.771-0.0900Dist+0.00001Dist }{ }^{2}+ \\
\text { 2.2425TotVol }\end{array}$ & 0.74 & 39.24 & 0.0001 & 129.57 \\
\hline
\end{tabular}

\subsubsection{Feller-buncher Felling}

\section{Elemental Times}

Total felling time - All productive elements of felling including drive to tree, cut, drive to dump, dump, and bunch for each tree provides us a total felling time for each individual tree. Mean total felling time differed significantly among species $(\mathrm{F}=5.58 ; \mathrm{df}=5,499 ; \mathrm{P}$ $=.0001), \mathrm{DBH}(\mathrm{F}=11.43 ; \mathrm{df}=4,499 ; \mathrm{P}=.0001)$, and merchantable length $(\mathrm{F}=11.95 ; \mathrm{df}$ $=3,499 ; \mathrm{P}=.0001)$ with ranges of .85 to 1.46 minutes, .79 to 1.85 minutes, and .89 to 1.78 minutes respectively (Table 3.5). A regression model was developed to estimate total felling time per tree (Table 3.6). Total felling time was best described by DBH and merchantable height of the tree being felled, distance to tree, and distance to dump.

Drive to tree - The density of the stand as well as the intensity of the harvest affect time moving to the tree to be cut because thinnings leave trees that must be maneuvered around. Drive to tree was the largest of the elemental times measured. There was a significant difference in drive to tree time among merchantable lengths $(F=9.54 ; \mathrm{df}=3$, 
$499 ; \mathrm{P}=.0001)$ with a range of .49 to 1.07 minutes. No significant differences were found in drive to tree time among species $(\mathrm{F}=2.13 ; \mathrm{df}=5,499 ; \mathrm{P}=.0611)$, with ranges of .45 to .86 minutes, or DBH classes $(\mathrm{F}=1.29 ; \mathrm{df}=4,499 ; \mathrm{P}=.2743)$, with a range of .44 to .70 minutes (Table 3.5 ).

$C u t$ - Time to cut a tree was significantly different among DBH $(\mathrm{F}=99.60 ; \mathrm{df}=4,499 ; \mathrm{P}$ $=.0001)$ ranging from .07 to .61 minutes, and merchantable length $(\mathrm{F}=9.85 ; \mathrm{df}=3,499$; $\mathrm{P}=.0001)$ ranging from .10 to .32 minutes. Cut time was not significantly different among species $(\mathrm{F}=0.43 ; \mathrm{df}=5,499 ; \mathrm{P}=.8252)$ with cut time ranging from .10 to .22 minutes (Table 3.5). A model developed using regression analysis allows estimation of cut time per tree (Table 3.6). It was found that cut time was affected by DBH and merchantable height of the tree.

Drive to dump - Drive to dump was not always performed in a feller-buncher felling cycle so it accounts for much less of total felling time than drive to tree. There were significant differences in drive to dump times for species $(\mathrm{F}=4.29$; $\mathrm{df}=5,499 ; \mathrm{P}=$ .0008 ) with times ranging from .02 to .09 minutes. No significant differences were found among DBH classes $(\mathrm{F}=1.38 ; \mathrm{df}=4,499 ; \mathrm{P}=.2409)$ with times ranging from 0 to .05 minutes or among merchantable length $(\mathrm{F}=.25 ; \mathrm{df}=3,499 ; \mathrm{P}=.8632)$ with a range of .03 to .05 minutes (Table 3.5 ).

Dump - Dump time was found to be significantly affected by DBH $(\mathrm{F}=4.88 ; \mathrm{df}=4,499$; $\mathrm{P}=.0007)$ ranging from .08 to .12 minutes. No significant difference was found for 
dump time among merchantable length $(\mathrm{F}=2.17 ; \mathrm{df}=3,499 ; \mathrm{P}=.0914)$ ranging from .09 to .11 minutes or species $(\mathrm{F}=0.93 ; \mathrm{df}=5,499 ; \mathrm{P}=.4598)$ ranging from .09 to .12 minutes (Table 3.5).

Bunch - Bunch time significantly differed among species $(\mathrm{F}=12.92 ; \mathrm{df}=5,499 ; \mathrm{P}=$ $.0001)$ ranging from .10 to .36 minutes and $\mathrm{DBH}(\mathrm{F}=7.64 ; \mathrm{df}=4,499 ; \mathrm{P}=.0001)$ ranging from .17 to .46 minutes. Bunch time did not differ significantly among merchantable length $(\mathrm{F}=2.60 ; \mathrm{df}=3,499 ; \mathrm{P}=.0518)$ ranging from .15 to .27 minutes (Table 3.5$)$.

Feller-buncher delay - Feller buncher delay was only observed 20 times during the study. Delay was usually due to maintenance of the saw and included replacing the chain when dull and the bar when bent. Some delay due to hydraulic line failure also occurred. Delay of the feller-buncher was not significantly different among species $(\mathrm{F}=0.84 ; \mathrm{df}=5$, 499; $\mathrm{P}=.5193), \mathrm{DBH}(\mathrm{F}=0.99 ; \mathrm{df}=4,499 ; \mathrm{P}=.4120)$, or merchantable length $(\mathrm{F}=$ $.1 .14 ; \mathrm{df}=3,499 ; \mathrm{P}=.3313$ ) with ranges of 0 to .91 minutes, 0 to .94 minutes, and .04 to 1.06 minutes respectively (Table 3.5).

Top/delimb - As stated previously, time the top/delimb procedure during the mechanized harvesting operation was very difficult. A total time for groups of trees of different sizes and species were taken and an average top/delimb time per tree was found for each group. This method of data collection provided no way to conduct a GLM model on the data to find significant differences among tree diameters, merchantable lengths, or 
species. Average top/ delimb time per tree was found to be 1.62 minutes and top/delimb delay per tree was found to be 0.20 minutes.

\section{$\underline{\text { Productivity }}$}

Felling Productivity - Observed productivity of the feller-buncher was not significantly different among species $(\mathrm{F}=2.22 ; \mathrm{df}=5,499 ; \mathrm{P}=.0515)$ and ranged from 939.8 to $1478.7 \mathrm{ft}$ 3/PMH (5638.8 to $8827.2 \mathrm{bd} \mathrm{ft} / \mathrm{PMH}$ ). Productivity did differ significantly among $\mathrm{DBH}(\mathrm{F}=66.17 ; \mathrm{df}=4,499 ; \mathrm{P}=.0001)$ and merchantable length $(\mathrm{F}=19.31 ; \mathrm{df}=$ 3,$499 ; \mathrm{P}=.0001$ ) with ranges from 428.9 to $2333.6 \mathrm{ft}^{3} / \mathrm{PMH}$ (2573.4 to $14001.6 \mathrm{bd}$ $\mathrm{ft} / \mathrm{PMH}$ ) and 638.4 to $2238.6 \mathrm{ft}$ /3/PMH (3830.4 to $13431.6 \mathrm{bd} \mathrm{ft/PMH),} \mathrm{respectively}$ (Table 3.5). A regression model was developed to estimate the productivity of the fellerbuncher (Table 3.6). Factors that affect felling productivity are DBH, merchantable height, and distance between harvested trees.

Top/Delimb Productivity - Again, with the difficulty in data collection, no significant difference in classes could be found for productivity of top/delimbing. Average observed productivity of the top/delimb was $726.30 \mathrm{ft}^{3} / \mathrm{PMH}$. A regression model was also developed to estimate the productivity of the top/delimbing (Table 3.6). DBH and merchantable length were found to best predict top/delimbing productivity. 
Table 3.5 - Means and significance levels of statistics for feller-buncher felling during time and motion studies. ${ }^{\mathrm{a}}$

\begin{tabular}{|c|c|c|c|c|c|c|c|c|}
\hline & \multicolumn{7}{|c|}{ Elemental Times (min) } & \multirow{2}{*}{$\begin{array}{c}\begin{array}{c}\text { Average Production } \\
\left(\mathbf{f t}^{3} / \mathbf{P M H}\right)\end{array} \\
\text { Felling Productivity }\end{array}$} \\
\hline & $\begin{array}{c}\text { Total Felling } \\
\text { Time }\end{array}$ & $\begin{array}{l}\text { Drive to } \\
\text { Tree }\end{array}$ & Cut & $\begin{array}{l}\text { Drive to } \\
\text { Dump }\end{array}$ & Dump & Bunch & $\begin{array}{l}\text { Feller- } \\
\text { Buncher } \\
\text { Delay }\end{array}$ & \\
\hline \multicolumn{9}{|l|}{ Species } \\
\hline Red Maple & $1.06 \mathrm{~A}$ & $0.51 \mathrm{AB}$ & $0.17 \mathrm{~A}$ & $0.03 \mathrm{~A}$ & $0.10 \mathrm{~A}$ & $0.25 \mathrm{~A}$ & $0.35 \mathrm{~A}$ & $1204 \mathrm{~A}$ \\
\hline Black Cherry & $0.85 \mathrm{~A}$ & $0.45 \mathrm{~B}$ & $0.15 \mathrm{~A}$ & $0.04 \mathrm{~A}$ & $0.12 \mathrm{~A}$ & $0.10 \mathrm{~B}$ & $0.00 \mathrm{~A}$ & 1386.1 AB \\
\hline Yellow Poplar & $1.46 \mathrm{~B}$ & $0.86 \mathrm{C}$ & $0.21 \mathrm{~B}$ & $0.09 \mathrm{~B}$ & $0.10 \mathrm{~A}$ & $0.20 \mathrm{AD}$ & $0.91 \mathrm{~A}$ & $1478.7 \mathrm{~B}$ \\
\hline Black Locust & $0.90 \mathrm{~A}$ & $0.51 \mathrm{AB}$ & $0.10 \mathrm{C}$ & $0.02 \mathrm{~A}$ & $0.11 \mathrm{~A}$ & $0.17 \mathrm{BD}$ & $0.85 \mathrm{~A}$ & $939.8 \mathrm{C}$ \\
\hline White Ash & $1.06 \mathrm{~A}$ & $0.62 \mathrm{AB}$ & $0.10 \mathrm{C}$ & $0.08 \mathrm{~B}$ & $0.09 \mathrm{~A}$ & $0.16 \mathrm{BD}$ & $0.00 \mathrm{~A}$ & $1162.1 \mathrm{AC}$ \\
\hline Other & $1.39 \mathrm{~B}$ & $0.70 \mathrm{BC}$ & $0.22 \mathrm{~B}$ & $0.02 \mathrm{~A}$ & $0.10 \mathrm{~A}$ & $0.36 \mathrm{E}$ & $0.41 \mathrm{~A}$ & $1297.3 \mathrm{AB}$ \\
\hline \multicolumn{9}{|l|}{ DBH (in) } \\
\hline 10 & $0.79 \mathrm{G}$ & $0.44 \mathrm{G}$ & $0.07 \mathrm{G}$ & $0.02 \mathrm{G}$ & $0.08 \mathrm{G}$ & $0.17 \mathrm{G}$ & $0.50 \mathrm{G}$ & $428.9 \mathrm{G}$ \\
\hline 15 & $0.99 \mathrm{GH}$ & $0.54 \mathrm{G}$ & $0.10 \mathrm{G}$ & $0.05 \mathrm{G}$ & $0.12 \mathrm{H}$ & $0.18 \mathrm{G}$ & $0.11 \mathrm{G}$ & $878.8 \mathrm{H}$ \\
\hline 20 & $1.15 \mathrm{HI}$ & $0.61 \mathrm{G}$ & $0.17 \mathrm{H}$ & $0.04 \mathrm{G}$ & $0.10 \mathrm{GH}$ & $0.23 \mathrm{G}$ & $0.50 \mathrm{G}$ & $1437.7 \mathrm{I}$ \\
\hline 25 & $1.28 \mathrm{I}$ & $0.65 \mathrm{G}$ & $0.29 \mathrm{I}$ & $0.03 \mathrm{G}$ & $0.11 \mathrm{G}$ & $0.20 \mathrm{G}$ & $0.94 \mathrm{G}$ & $2333.6 \mathrm{~J}$ \\
\hline 30 & $1.85 \mathrm{~J}$ & $0.70 \mathrm{G}$ & $0.61 \mathrm{~J}$ & $0.00 \mathrm{G}$ & $0.08 \mathrm{H}$ & $0.46 \mathrm{H}$ & $0.00 \mathrm{G}$ & $2267.7 \mathrm{~J}$ \\
\hline \multicolumn{9}{|l|}{ Length (ft) } \\
\hline 8 & $0.89 \mathrm{~L}$ & $0.49 \mathrm{~L}$ & $0.10 \mathrm{~L}$ & $0.03 \mathrm{~L}$ & $0.11 \mathrm{~L}$ & $0.15 \mathrm{~L}$ & $0.23 \mathrm{~L}$ & $638.4 \mathrm{~L}$ \\
\hline 16 & $1.04 \mathrm{LM}$ & $0.55 \mathrm{~L}$ & $0.14 \mathrm{~L}$ & $0.04 \mathrm{~L}$ & $0.10 \mathrm{LM}$ & $0.21 \mathrm{LM}$ & $0.45 \mathrm{~L}$ & $1180.1 \mathrm{M}$ \\
\hline 24 & $1.18 \mathrm{M}$ & $0.52 \mathrm{~L}$ & $0.26 \mathrm{M}$ & $0.05 \mathrm{~L}$ & $0.11 \mathrm{~L}$ & $0.25 \mathrm{~L}$ & $0.04 \mathrm{~L}$ & $1910.1 \mathrm{~N}$ \\
\hline 32 & $1.78 \mathrm{~N}$ & $1.07 \mathrm{M}$ & $0.32 \mathrm{~N}$ & $0.03 \mathrm{~L}$ & $0.09 \mathrm{M}$ & $0.27 \mathrm{~L}$ & $1.06 \mathrm{~L}$ & 2238.60 \\
\hline
\end{tabular}

Table 3.6 - Models to estimate feller-buncher felling times and productivities.

\begin{tabular}{llcccc}
\hline \hline & Models $^{\mathrm{a}}$ & $\mathrm{R}^{2}$ & RMSE & P-value & F-value \\
\hline Cut Time per tree (min) & $\begin{array}{l}0.24-0.04 \mathrm{DBH}+0.007 \mathrm{~L}+0.0005 \mathrm{DBH} \\
* \mathrm{~L}+0.0015 \mathrm{DBH}^{2}-0.00035 \mathrm{~L}^{2}\end{array}$ & 0.46 & 0.13 & 0.0001 & 83.44 \\
& $\begin{array}{l}0.367+0.0008 \mathrm{DBH}^{2}+0.00026 \mathrm{~L}^{2}+0.02246 \\
\text { Total felling time per tree } \\
\text { (min) }\end{array}$ & 0.61 & 0.45 & 0.0001 & 192.86 \\
$\begin{array}{l}\text { Feller-buncher productivity } \\
\text { 3/PMH) }\end{array}$ & $\begin{array}{l}\mathrm{Dist}+0.00679 \mathrm{DistD} \\
\text { Top/Delimb productivity }\end{array}$ & 0.55 & 685.9 & 0.0001 & 198.93 \\
3/PMH) & (ft 365.95-56.19DBH- \\
$14.39 \mathrm{~L}+3.81 \mathrm{DBH} * \mathrm{~L}+2.22 \mathrm{DBH}^{2}-0.63 \mathrm{~L}^{2}$ & & 0.83 & 248.36 & 0.0001 & 486.71 \\
\hline \hline
\end{tabular}

${ }^{\mathrm{a}} \mathrm{DBH}=$ diameter at breast height (in); $\mathrm{L}=$ merchantable length (ft); Dist $\mathrm{T}=$ distance to tree (ft); DistD = distance to dump (ft); RMSE $=$ root of mean square error 


\subsubsection{Grapple Skidding}

\section{$\underline{\text { Elemental Times }}$}

Total skidding time - All productive elements of skidding time including travel empty, grapple, travel loaded, and release for each turn gives us a total skidding time for each turn. Mean total skidding times differed significantly among average DBH per turn $(\mathrm{F}=21.41 ; \mathrm{df}=4,149 ; \mathrm{P}=.0001)$, merchantable length per turn $(\mathrm{F}=99.50 ; \mathrm{df}=5,149 ; \mathrm{P}$ $=.0001)$, number of logs per turn $(\mathrm{F}=35.68 ; \mathrm{df}=4,149 ; \mathrm{P}=.0001)$, total volume per turn $(\mathrm{F}=11.85 ; \mathrm{df}=6,149 ; \mathrm{P}=.0001)$, and skidding distance $(\mathrm{F}=168.27 ; \mathrm{df}=3,149 ; \mathrm{P}=$ .0001 ) with range s of 10.23 to $13.47,8.33$ to $14.48,10.06$ to 13.17 minutes, 8.70 to 14.88 minutes, and 5.94 to 17.58 minutes, respectively (Table 3.7). Significant differences were also found in travel loaded time among interactions between average diameter and average length, average diameter and skidding distance, average length and skidding distance, total volume and skidding distance, and number of logs and skidding distance. A regression model was developed to estimate total skidding time (Table 3.8). Total skidding time was best described by skidding distance and total volume in cubic feet per turn.

Travel empty - Mean travel empty time ranged from 2.07 to 5.70 minutes and showed a significant difference among skidding distance $(\mathrm{F}=95.05 ; \mathrm{df}=3,149 ; \mathrm{P}=.0001)$ (Table 3.7). A model developed using regression analysis allows estimation of travel empty 
time (Table 3.8). It was found that travel empty time was solely affected by skidding distance.

Grapple-Mean grapple time differed significantly among DBH classes $(\mathrm{F}=11.27 ; \mathrm{df}=4$, $149 ; \mathrm{P}=.0001)$, merchantable length $(\mathrm{F}=12.91 ; \mathrm{df}=5,149 ; \mathrm{P}=.0001)$, and total volume per turn $(\mathrm{F}=2.38 ; \mathrm{df}=6,149 ; \mathrm{P}=.0379)$ with ranges of 1.00 to 2.69 minutes, 1.19 to 2.77 minutes, and 1.00 to 2.18 minutes, respectively. No significant difference was found in grapple time among number of $\operatorname{logs}$ per turn $(\mathrm{F}=1.45 ; \mathrm{df}=4,149 ; \mathrm{P}=.2272)$ with a range of 1.17 to 2.31 minutes (Table 3.7). There was also a significant difference in grapple time among the interaction between average diameter and average length.

Travel Loaded - There were significant differences in travel loaded times among DBH classes $(\mathrm{F}=36.52 ; \mathrm{df}=4,149 ; \mathrm{P}=.0001)$, merchantable lengths $(\mathrm{F}=64.63 ; \mathrm{df}=5,149 ; \mathrm{P}$ $=.0001)$, number of logs $(\mathrm{F}=35.81 ; \mathrm{df}=4,149 ; \mathrm{P}=.0001)$, total payload $(\mathrm{F}=15.87 ; \mathrm{df}=$ $6,149 ; \mathrm{P}=.0001)$, and skidding distance $(\mathrm{F}=170.55 ; \mathrm{df}=3,149 ; \mathrm{P}=.0001)$ with times ranging from 4.99 to 7.48 minutes, 3.87 to 7.56 minutes, 5.15 to 6.75 minutes, 3.84 to 8.59 minutes, and 2.77 to 10.18 minutes, respectively (Table 3.7). Significant differences were also found in travel loaded time among interactions between average diameter and average length, average diameter and skidding distance, average length and skidding distance, total volume and skidding distance, and number of logs and skidding distance. A model developed using regression analysis allows estimation of travel loaded time (Table 3.8). It was found that travel loaded time was affected by skidding distance and total volume per turn. 
Release - Release time was not found to be significantly affected among DBH classes $(\mathrm{F}=1.22 ; \mathrm{df}=4,149 ; \mathrm{P}=.3095)$ or number of $\operatorname{logs}(\mathrm{F}=0.91 ; \mathrm{df}=4,149 ; \mathrm{P}=.4626)$ with an average time of .02 minutes. Release time was found to be significantly different among merchantable length $(\mathrm{F}=6.08 ; \mathrm{df}=5,149 ; \mathrm{P}=.0001)$ and total volume per turn $(\mathrm{F}=2.33 ; \mathrm{df}=6,149 ; \mathrm{P}=.0412)$ with both ranging from .02 to .03 minutes (Table 3.7$)$. There was also a significant difference in release time among the interaction between average diameter and length.

Delay - Grapple skidding delay was only observed 2 times during the study. Delay of the grapple skidder was not significantly different among DBH classes $(F=0.78 ; \mathrm{df}=4$, $149 ; \mathrm{P}=.5446)$, merchantable length $(\mathrm{F}=0.81 ; \mathrm{df}=5,149 ; \mathrm{P}=.5440)$, number of $\operatorname{logs}$ per turn $(\mathrm{F}=0.63 ; \mathrm{df}=4,149 ; \mathrm{P}=.6442)$, total volume per turn $(\mathrm{F}=0.71 ; \mathrm{df}=6,149 ; \mathrm{P}=$ $.6390)$, or skidding distance $(\mathrm{F}=0.07 ; \mathrm{df}=3,149 ; \mathrm{P}=.9768)$ with ranges of 0 to .93 minutes, 0 to 1.02 minutes, 0 to 0.74 minutes, 0 to 1.55 minutes, and 0 to 0.57 minutes, respectively (Table 3.7$)$.

\section{Productivity}

Observed productivity of grapple skidding was significantly different among DBH classes $(\mathrm{F}=27.49 ; \mathrm{df}=4,149 ; \mathrm{P}=.0001)$, merchantable length $(\mathrm{F}=4.51 ; \mathrm{df}=5$, $149 ; \mathrm{P}=.0013)$, number of $\operatorname{logs}(\mathrm{F}=3.67 ; \mathrm{df}=4,149 ; \mathrm{P}=.0089)$, total payload $(\mathrm{F}=4.30$; $\mathrm{df}=6,149 ; \mathrm{P}=.0009)$, and skidding distance $(\mathrm{F}=59.09 ; \mathrm{df}=3,149 ; \mathrm{P}=.0001)$ with 
ranges of 290.66 to $639.95 \mathrm{ft} 3 / \mathrm{PMH}$ (1743.96 to $3839.7 \mathrm{bd} \mathrm{ft} / \mathrm{PMH}$ ), 387.42 to 646.18 $\mathrm{ft}^{3} / \mathrm{PMH}$ (1664.22 to $\left.3877.08 \mathrm{bd} \mathrm{ft} / \mathrm{PMH}\right), 404.96$ to $643.96 \mathrm{ft}^{3} / \mathrm{PMH}$ (2429.76 to 3863.76 bd ft/PMH), 262.36 to $708.65 \mathrm{ft}^{3} / \mathrm{PMH}$ (1574.16 to $4251.9 \mathrm{bd} \mathrm{ft} / \mathrm{PMH}$ ), and 401.83 to $828.88 \mathrm{ft}^{3} / \mathrm{PMH}$ (2410.98 to $4973.28 \mathrm{bd} \mathrm{ft} / \mathrm{PMH}$ ), respectively (Table 3.7). Significant differences were also found in productivity among the interactions between average diameter and skidding distance, and number of logs per turn and skidding distance. A regression model was developed to estimate the productivity of the grapple skidding (Table 3.8). Factors that affect grapple skidding productivity are skidding distance and total turn payload. 
Table 3.7 - Means and significance levels of statistics for grapple skidding during time and motion studies. ${ }^{a}$

\begin{tabular}{|c|c|c|c|c|c|c|c|}
\hline & \multicolumn{6}{|c|}{ Elemental Times (min) } & \multirow{2}{*}{$\begin{array}{c}\begin{array}{c}\text { Average Production } \\
\text { (ft } \mathbf{3} / \mathbf{P M H} \text { ) }\end{array} \\
\text { Skidding } \\
\text { Productivity }\end{array}$} \\
\hline & $\begin{array}{c}\text { Total } \\
\text { Skidding } \\
\text { Time }\end{array}$ & Travel Empty & Grapple & $\begin{array}{c}\text { Travel } \\
\text { Loaded }\end{array}$ & Release & Delay & \\
\hline \multicolumn{8}{|c|}{ Average } \\
\hline 12 & $11.65 \mathrm{AB}$ & N/A & $2.69 \mathrm{~A}$ & $4.99 \mathrm{~A}$ & $0.02 \mathrm{~A}$ & $0.93 \mathrm{~A}$ & $290.66 \mathrm{~A}$ \\
\hline 14 & $10.23 \mathrm{~A}$ & N/A & $1.56 \mathrm{~B}$ & $5.19 \mathrm{~A}$ & $0.02 \mathrm{~A}$ & $0.00 \mathrm{~A}$ & $505.93 \mathrm{~B}$ \\
\hline 16 & $11.19 \mathrm{~A}$ & N/A & $1.63 \mathrm{~B}$ & $5.60 \mathrm{AB}$ & $0.02 \mathrm{~A}$ & $0.00 \mathrm{~A}$ & $623.71 \mathrm{~B}$ \\
\hline 18 & $11.84 \mathrm{AB}$ & N/A & $1.00 \mathrm{~B}$ & $6.69 \mathrm{BC}$ & $0.02 \mathrm{~A}$ & $0.00 \mathrm{~A}$ & $628.41 \mathrm{~B}$ \\
\hline 20 & $13.47 \mathrm{~B}$ & N/A & $1.57 \mathrm{~B}$ & $7.48 \mathrm{C}$ & $0.02 \mathrm{~A}$ & $0.00 \mathrm{~A}$ & $639.95 \mathrm{~B}$ \\
\hline \multicolumn{8}{|c|}{ Average } \\
\hline \multicolumn{8}{|c|}{ Length (ft) } \\
\hline 20 & $8.33 \mathrm{~A}$ & N/A & $1.28 \mathrm{~A}$ & $3.87 \mathrm{~A}$ & $0.02 \mathrm{~A}$ & $0.00 \mathrm{~A}$ & $387.42 \mathrm{~A}$ \\
\hline 25 & $8.95 \mathrm{~A}$ & N/A & $1.71 \mathrm{~A}$ & $4.11 \mathrm{~A}$ & $0.02 \mathrm{~A}$ & $0.00 \mathrm{~A}$ & $544.04 \mathrm{AB}$ \\
\hline 30 & $11.77 \mathrm{~B}$ & N/A & $2.02 \mathrm{AB}$ & $5.78 \mathrm{~B}$ & $0.02 \mathrm{~A}$ & $1.02 \mathrm{~A}$ & $520.06 \mathrm{AB}$ \\
\hline 35 & $14.48 \mathrm{C}$ & N/A & 2.77 B & $7.12 \mathrm{C}$ & $0.03 \mathrm{~B}$ & $0.00 \mathrm{~A}$ & $545.34 \mathrm{AB}$ \\
\hline 40 & $13.53 \mathrm{BC}$ & N/A & $1.75 \mathrm{~A}$ & $7.25 \mathrm{C}$ & $0.02 \mathrm{~A}$ & $0.00 \mathrm{~A}$ & $546.21 \mathrm{AB}$ \\
\hline 45 & $13.29 \mathrm{BC}$ & N/A & $1.19 \mathrm{~A}$ & $7.56 \mathrm{C}$ & $0.02 \mathrm{~A}$ & $0.00 \mathrm{~A}$ & 646.18 B \\
\hline \multicolumn{8}{|c|}{ Number of Logs } \\
\hline 2 & $11.80 \mathrm{~B}$ & N/A & $1.17 \mathrm{~A}$ & $6.60 \mathrm{C}$ & $.02 \mathrm{~A}$ & $0.00 \mathrm{~A}$ & $643.96 \mathrm{~A}$ \\
\hline 3 & $10.06 \mathrm{~A}$ & N/A & $1.30 \mathrm{AB}$ & $5.15 \mathrm{~A}$ & $.02 \mathrm{~A}$ & $0.00 \mathrm{~A}$ & 536.77 B \\
\hline 4 & $10.79 \mathrm{~A}$ & N/A & $1.90 \mathrm{BC}$ & $5.20 \mathrm{~A}$ & $.02 \mathrm{~A}$ & $0.00 \mathrm{~A}$ & $476.01 \mathrm{BC}$ \\
\hline 5 & $12.41 \mathrm{BC}$ & N/A & $2.31 \mathrm{C}$ & $6.01 \mathrm{~B}$ & $.02 \mathrm{~A}$ & $0.74 \mathrm{~A}$ & $506.91 \mathrm{~B}$ \\
\hline 6 & $13.17 \mathrm{C}$ & N/A & $1.81 \mathrm{BC}$ & $6.75 \mathrm{C}$ & $.02 \mathrm{~A}$ & $0.00 \mathrm{~A}$ & $404.96 \mathrm{C}$ \\
\hline \multicolumn{8}{|c|}{ Total Volume $\mathbf{f t}^{3}$} \\
\hline 40 & $9.08 \mathrm{~A}$ & N/A & $2.05 \mathrm{~A}$ & $3.84 \mathrm{~A}$ & $.03 \mathrm{~A}$ & $0.00 \mathrm{~A}$ & $262.36 \mathrm{~A}$ \\
\hline 60 & $8.70 \mathrm{~A}$ & N/A & $1.47 \mathrm{AB}$ & $4.06 \mathrm{~A}$ & $.02 \mathrm{~B}$ & $0.00 \mathrm{~A}$ & $467.57 \mathrm{~B}$ \\
\hline 80 & $10.27 \mathrm{~B}$ & N/A & $2.01 \mathrm{~A}$ & $4.66 \mathrm{~B}$ & $.02 \mathrm{AB}$ & $1.55 \mathrm{~A}$ & $505.65 \mathrm{~B}$ \\
\hline 100 & $11.69 \mathrm{C}$ & N/A & $2.18 \mathrm{~A}$ & $5.71 \mathrm{C}$ & $.02 \mathrm{~B}$ & $0.00 \mathrm{~A}$ & $565.66 \mathrm{~B}$ \\
\hline 120 & $14.88 \mathrm{D}$ & N/A & $1.97 \mathrm{~A}$ & $7.83 \mathrm{D}$ & $.02 \mathrm{AB}$ & $0.00 \mathrm{~A}$ & $473.16 \mathrm{~B}$ \\
\hline 140 & $14.25 \mathrm{D}$ & N/A & $1.85 \mathrm{~A}$ & $7.59 \mathrm{D}$ & $.02 \mathrm{AB}$ & $0.00 \mathrm{~A}$ & $574.54 \mathrm{~B}$ \\
\hline 160 & $14.23 \mathrm{D}$ & N/A & $1.00 \mathrm{~B}$ & $8.59 \mathrm{E}$ & $.02 \mathrm{AB}$ & $0.00 \mathrm{~A}$ & $708.65 \mathrm{C}$ \\
\hline \multicolumn{8}{|c|}{ Skidding Distance (ft) } \\
\hline 1500 & $5.94 \mathrm{~A}$ & $2.07 \mathrm{~A}$ & N/A & $2.77 \mathrm{~A}$ & N/A & $0.00 \mathrm{~A}$ & $828.88 \mathrm{~A}$ \\
\hline 2000 & $9.95 \mathrm{~B}$ & $3.56 \mathrm{~B}$ & N/A & $4.53 \mathrm{~B}$ & N/A & $0.00 \mathrm{~A}$ & $438.70 \mathrm{~B}$ \\
\hline 2500 & $12.84 \mathrm{C}$ & $4.34 \mathrm{C}$ & N/A & $6.36 \mathrm{C}$ & N/A & $0.57 \mathrm{~A}$ & $446.88 \mathrm{~B}$ \\
\hline 3000 & $17.58 \mathrm{D}$ & $5.70 \mathrm{D}$ & N/A & $10.18 \mathrm{D}$ & N/A & $0.00 \mathrm{~A}$ & $401.83 \mathrm{~B}$ \\
\hline
\end{tabular}

${ }^{a}$ Means with the same capital letter in a column are not significantly different at the 5 percent level with

Duncan's Multiple-Range Test. 
Table 3.8 - Models to estimate grapple skidding times and productivities.

\begin{tabular}{|c|c|c|c|c|c|}
\hline & Models $^{a}$ & $\mathrm{R}^{2}$ & RMSE & P-value & $\mathrm{F}$ - value \\
\hline Travel empty (min) & $0.2287+0.0018$ Dist & 0.78 & 0.64 & 0.0001 & 516.6 \\
\hline Travel loaded (min) & $0.1325+0.0000008 \mathrm{Dist}^{2}+0.0234 \mathrm{TotVol}$ & 0.83 & 1.11 & 0.0001 & 352.69 \\
\hline Total time per turn (min & $\begin{array}{l}.8440+0.00272 \text { Dist+0.0000007Dist }{ }^{2}+ \\
0.0220 \text { TotVol }\end{array}$ & 0.78 & 2.05 & 0.0001 & 176.94 \\
\hline $\begin{array}{l}\text { Skidding productivity } \\
\left(\mathrm{ft}^{3} / \mathrm{PMH}\right)\end{array}$ & $\begin{array}{l}\text { 1370.1472-1.0060Dist+0.0002 } \text { Dist }^{2}+ \\
\text { 4.4502TotVol }\end{array}$ & 0.71 & 179.32 & 0.0001 & 118.18 \\
\hline
\end{tabular}

${ }^{\mathrm{a}}$ Dist $=$ Skidding distance one way $(\mathrm{ft}) ;$ Totvol = Total volume per turn $\left(\mathrm{ft}^{3}\right) ; \mathrm{RMSE}=$ root of mean square error

\subsubsection{Cost Analysis}

Cost information about each machine observed was obtained from the loggers

(Table 3.9). Estimates of productive machine hour (PMH) costs were calculated using the machine rate method (Miyata, 1980).

Table 3.9 - Machine rate specifications

\begin{tabular}{|c|c|c|c|c|c|}
\hline & $\begin{array}{l}\text { Chainsaw } \\
\text { Felling }\end{array}$ & $\begin{array}{c}\text { Cable } \\
\text { Skidding }\end{array}$ & $\begin{array}{l}\text { Feller- } \\
\text { buncher } \\
\text { Felling }\end{array}$ & Top/Delimbing & $\begin{array}{l}\text { Grapple } \\
\text { Skidding }\end{array}$ \\
\hline Make and Model & $\begin{array}{l}\text { Husqvarna } \\
\quad 372\end{array}$ & $\begin{array}{c}\text { Timberjack } \\
460\end{array}$ & $\begin{array}{c}\text { Timbco } 445- \\
\text { C }\end{array}$ & Husqvarna 55 & $\begin{array}{c}\text { Timberjack } \\
460\end{array}$ \\
\hline Purchase Price & $\$ 600$ & $\$ 130,000$ & $\$ 225,000$ & $\$ 300$ & $\$ 130,000$ \\
\hline $\begin{array}{l}\text { Estimated Life } \\
\text { (years) }\end{array}$ & 1 & 3 & 4 & 0.5 & 3 \\
\hline Salvage Value & $\$ 0$ & $\$ 25,040$ & $\$ 45,000$ & $\$ 0$ & $\$ 24,560$ \\
\hline $\begin{array}{l}\text { Interest, Insurance, } \\
\& \text { Taxes ( } \% \text { of } \\
\text { purchase price) }\end{array}$ & N/A & $16 \%$ & $16 \%$ & N/A & $16 \%$ \\
\hline $\begin{array}{l}\text { Scheduled Hours } \\
(\mathrm{hr} / \mathrm{yr})\end{array}$ & 2000 & 2000 & 2000 & 2000 & 2000 \\
\hline Operator Cost & $\begin{array}{l}\$ 10 / \text { hour }+ \\
35 \% \text { fringe }\end{array}$ & $\begin{array}{l}\$ 10 / \text { hour }+ \\
35 \% \text { fringe }\end{array}$ & $\begin{array}{l}\$ 10 / \text { hour }+ \\
35 \% \text { fringe }\end{array}$ & $\begin{array}{c}\$ 10 / \text { hour }+35 \% \\
\text { fringe }\end{array}$ & $\begin{array}{l}\$ 10 / \text { hour }+ \\
35 \% \text { fringe }\end{array}$ \\
\hline
\end{tabular}




\subsubsection{Chainsaw Felling}

The chainsaw used in manual felling cost $\$ 600$ and lasted approximate 1 year. After that time, no salvage value was expected. Fixed costs were calculated to be $\$ 0.60 / \mathrm{PMH}$ and operating cost were calculated at $\$ 1.39 / \mathrm{PMH}$. Labor cost was calculated at $\$ 27.00 / \mathrm{PMH}$. Total cost for manual felling including labor was estimated to be \$28.99/PMH. All costs were converted to dollars per scheduled machine hour (\$/SMH) by multiplying the $\$ / \mathrm{PMH}$ by the utilization rate of the machine. An average productivity of $363.4 \mathrm{ft} 3 / \mathrm{PMH}$ (2180.4 bd ft/PMH) allowed an estimated average cost per volume of $\$ 0.08 / \mathrm{ft}^{3}$ (\$0.013/bd ft) for manual chainsaw felling (Table 3.10).

\subsubsection{Cable Skidding}

The cable skidder was purchased in 1999 for \$130,000. After an anticipated economic life of 5 years, salvage value would be $\$ 25,040$. Operator cost was assumed to be $\$ 10 / \mathrm{hr}$ with fringe benefits of $35 \%$. Fixed costs were calculated to be $\$ 35.88 / \mathrm{PMH}$ and operating cost were calculated at $\$ 22.57 / \mathrm{PMH}$. Labor cost was calculated to be $\$ 20.15 / \mathrm{PMH}$. Total cost to operate the machine including labor was estimated to be \$78.60/PMH. All costs were converted to dollars per scheduled machine hour (\$/SMH) by multiplying the $\$ / \mathrm{PMH}$ by the utilization rate of the machine. An average productivity of $289.4 \mathrm{ft}^{3} / \mathrm{PMH}$ (1736.4 bd ft/PMH) allowed an estimated average cost per volume of $\$ 0.27 / \mathrm{ft}^{3}$ ( $\$ 0.05 / \mathrm{bd} \mathrm{ft}$ ) for the cable skidder (Table 3.10). 
Table 3.10 - Manaual harvesting machine rate calculations

\begin{tabular}{lcc}
\hline \hline Chainsaw Felling & $(\$ / \mathrm{PMH})$ & $(\$ / \mathrm{SMH})$ \\
\hline Fixed Cost & $\$ 0.60$ & $\$ 0.30$ \\
Variable Cost & $\$ 1.39$ & $\$ 0.70$ \\
Labor Cost & $\$ 27.00$ & $\$ 13.50$ \\
\hline Total Cost & $\$ 28.99$ & $\$ 14.50$ \\
Production & $363.4 \mathrm{ft}^{3} / \mathrm{PMH}$ & $181.7 \mathrm{ft}^{3} / \mathrm{SMH}$ \\
Unit Cost & $\$ 0.08 / \mathrm{ft}^{3}$ & \\
& & \\
Cable Skidding & & \\
\hline Fixed Cost & $\$ 35.88$ & $\$ 24.04$ \\
Variable Cost & $\$ 22.57$ & $\$ 15.12$ \\
Labor Cost & $\$ 20.15$ & $\$ 13.50$ \\
\hline Total Cost & $\$ 78.60$ & $\$ 52.66$ \\
Production & $289.4 \mathrm{ft}^{3} / \mathrm{PMH}$ & $193.9 \mathrm{ft}^{3} / \mathrm{SMH}$ \\
Unit Cost & $\$ 0.27 / \mathrm{ft}^{3}$ & \\
\hline \hline
\end{tabular}

$\mathrm{PMH}=$ productive machine hour; $\mathrm{SMH}=$ scheduled machine hour

\subsubsection{Feller-buncher Felling}

The feller-buncher was purchased for $\$ 225,000$ in 1998 and was in used condition with 2300 hours from the previous owner. After an anticipated econo mic life of 4 years, salvage value would be $\$ 45,000$. Operator cost was assumed to be $\$ 10 / \mathrm{hr}$ with fringe benefits of $35 \%$. Fixed costs were calculated to be $\$ 54.00 / \mathrm{PMH}$ and operating cost were calculated at $\$ 27.32 / \mathrm{PMH}$. Labor cost was calculated to be $\$ 20.77 / \mathrm{PMH}$. Total cost to operate feller-buncher including labor was estimated to be $\$ 102.09 / \mathrm{PMH}$. The chainsaw used to top/delimb costs $\$ 300$ and has an economic life of 6 months, after which time there is no salvage value. Total cost was estimated to be $\$ 28.23 / \mathrm{PMH}$. All costs were converted to dollars per scheduled machine hour (\$/SMH) by multiplying the $\$ / \mathrm{PMH}$ by the utilization rate of the machine. An average productivity of $1266.6 \mathrm{ft}^{3} / \mathrm{PMH}(7599.6$ 
bd ft/PMH) for felling and $726.3 \mathrm{ft} 3 / \mathrm{PMH}$ (4357.8 bd ft/PMH) for top/delimbing allowed an estimated average cost per volume of $\$ 0.08 / \mathrm{ft}^{3}(\$ 0.013 / \mathrm{bd} \mathrm{ft})$ for the feller-buncher and $\$ 0.04 / \mathrm{ft}^{3}$ (\$0.007/bd ft) for the top/delimbing (Table 3.11).

\subsubsection{Grapple Skidding}

The grapple skidder was purchased in 1999 for $\$ 130,000$. After an anticipated economic life of 5 years, salvage value would be $\$ 24,560$. Operator cost was assumed to be $\$ 10 / \mathrm{hr}$ with fringe benefits of $35 \%$. Fixed costs were calculated to be $\$ 35.19 / \mathrm{PMH}$ and operating cost were calculated at $\$ 27.75 / \mathrm{PMH}$. Labor cost was calculated to be $\$ 20.15 / \mathrm{PMH}$. Total cost to operate the grapple skidder including labor was estimated to be $\$ 83.09 / \mathrm{PMH}$. All costs were converted to dollars per scheduled machine hour (\$/SMH) by multiplying the $\$ / \mathrm{PMH}$ by the utilization rate of the machine. An average productivity of $512.1 \mathrm{ft} 3 / \mathrm{PMH}$ (3072.6 bd ft/PMH) allowed an estimated average cost per volume of $\$ 0.16 / \mathrm{ft}^{3}$ ( $\$ 0.03 / \mathrm{bd} \mathrm{ft}$ ) for the grapple skidder (Table 3.11). 
Table 3.11 - Mechanical harvesting machine rate calculations

\begin{tabular}{lcc}
\hline \hline & $(\$ / \mathrm{PMH})$ & $(\$ / \mathrm{SMH})$ \\
\hline Feller-buncher Felling & $\$ 54.00$ & $\$ 35.10$ \\
Vixed Cost & $\$ 27.32$ & $\$ 17.76$ \\
Labiable Cost & $\$ 20.77$ & $\$ 13.50$ \\
\hline Total Cost & $\$ 102.09$ & $\$ 66.36$ \\
Production & $1266.6 \mathrm{ft}^{3} / \mathrm{PMH}$ & $823.29 \mathrm{ft}^{3} / \mathrm{SMH}$ \\
Unit Cost & $\$ 0.08 / \mathrm{ft}^{3}$ & \\
& & \\
Top/delimbing & & \\
\hline Fixed Cost & $\$ 0.60$ & $\$ 0.30$ \\
Variable Cost & $\$ 0.63$ & $\$ 0.32$ \\
Labor Cost & $\$ 27.00$ & $\$ 13.50$ \\
\hline Total Cost & $\$ 28.23$ & $\$ 14.12$ \\
Production & $726.3 \mathrm{ft}^{3} / \mathrm{PMH}$ & $363.15 \mathrm{ft}^{3} / \mathrm{SMH}$ \\
Unit Cost & $\$ 0.04 / \mathrm{ft}^{3}$ & \\
& & \\
Grapple Skidding & & \\
\hline Fixed Cost & $\$ 35.19$ & \\
Variable Cost & $\$ 27.75$ & $\$ 18.59$ \\
Labor Cost & $\$ 20.15$ & $\$ 13.50$ \\
\hline Total Cost & $\$ 83.09$ & $\$ 55.67$ \\
Production & $512.1 \mathrm{ft}^{3} / \mathrm{PMH}$ & $358.47 \mathrm{ft}^{3} / \mathrm{SMH}$ \\
Unit Cost & $\$ 0.16 / \mathrm{ft}^{3}$ & \\
\hline \hline
\end{tabular}

$\mathrm{PMH}=$ productive machine hour; $\mathrm{SMH}=$ scheduled machine hour 


\section{CHAPTER 4 - CONCLUSIONS AND DISCUSSION}

\subsection{Production and Cost}

\section{(1) Chainsaw Felling}

Total felling time was mostly affected by DBH of the tree being felled but was also affected by the distance between trees being felled. Cut and top/delimb times were most affected by DBH of the tree being harvested. Productivity of manual felling was mostly affected by the distance between trees being felled but was also affected by interaction between DBH and merchantable length of the tree being harvested. An average productivity of $363.4 \mathrm{ft} 3 / \mathrm{PMH}(2180.4 \mathrm{bd} \mathrm{ft} / \mathrm{PMH})$ and $181.70 \mathrm{ft} 3 / \mathrm{SMH}(1090.2$ bd ft/SMH) provided a weekly production of $7268 \mathrm{ft}^{3}$ (43608 bd ft) with chainsaw felling. This productivity was the lowest among the machines examined in the study. Costs for chainsaw felling were lower than all other machines except for top/delimbing with chainsaw in the mechanized system. Total cost per productive machine hour (PMH), including labor, was $\$ 28.99$. Total cost per scheduled machine hour (SMH), including labor, of $\$ 14.50$ allowed for a weekly cost of $\$ 580.00$.

\section{(2) Cable Skidding}

Total skidding and travel loaded times as well as cable skidding productivity were primarily affected by turn payload of the skid but skidding distance was also a factor. Travel empty was solely affected by distance of the skid. Hourly production for cable 
skidding was $289.4 \mathrm{ft}^{3} / \mathrm{PMH}(1736.4 \mathrm{bd} \mathrm{ft} / \mathrm{PMH})$ and $188.11 \mathrm{ft}^{3} / \mathrm{SMH}(1128.66 \mathrm{bd}$ $\mathrm{ft} / \mathrm{SMH})$ with a weekly production of $7524.4 \mathrm{ft}^{3}(45146.4 \mathrm{bd} \mathrm{ft})$. This was the second lowest production of any machine examined. Total cost for the cable skidder including labor was $\$ 78.60 / \mathrm{PMH}$ and $\$ 51.71 / \mathrm{SMH}$ and weekly cost was $\$ 2068.40$. Only chainsaws had a lower cost than the cable skidder.

\section{(3) Feller-buncher Felling}

Total feller-buncher felling time was most affected by distance between harvested trees. This can be explained by the fact that drive to tree was a major part of the work cycle making up nearly half of the average work cycle. Cut time per tree was most affected by DBH of the tree harvested. Productivity of the feller-buncher was most affected by merchantable height and DBH. Top/delimbing productivity was most affected by DBH and merchantable height. Among species, yellow poplar yielded the highest productivity. This was probably due to its large size and straight boles compared to other hardwoods. Production of the feller-buncher was $1266.6 \mathrm{ft}^{3} / \mathrm{PMH}$ (7599.6 bd $\mathrm{ft} / \mathrm{PMH})$ and $823.29 \mathrm{ft}$ /SMH (4939.74 bd ft/SMH) with a weekly production of 32931.6 $\mathrm{ft}^{3}$ (197589.6 bd ft). The feller-buncher had extremely high production when compared to other machines examined. Costs for the feller-buncher including labor were $\$ 102.09 / \mathrm{PMH}$ and $\$ 64.06 / \mathrm{SMH}$ with a weekly cost of $\$ 2562.40$. These costs were higher than any other machine examined in the study. Production of top/delimbing was $726.3 \mathrm{ft} 3 / \mathrm{PMH}(4357.8 \mathrm{bd} \mathrm{ft} / \mathrm{PMH})$ and $363.15 \mathrm{ft}^{3} / \mathrm{SMH}(2178.9 \mathrm{bd} \mathrm{ft} / \mathrm{SMH})$ with a weekly production of $14526 \mathrm{ft}^{3}$ (87156 bd ft). Costs for top/delimbing including labor were $\$ 28.23 / \mathrm{PMH}$ and $\$ 14.11 / \mathrm{SMH}$ with a weekly cost of $\$ 564.40$. 


\section{(4) Grapple Skidding}

Similarly, total skidding and travel loaded times as well as grapple skidding productivity were mostly affected by total volume of the skidder per turn but skidding distance was also a factor. Travel empty was solely affected by skidding distance. Production of the grapple skidder was $512.1 \mathrm{ft}^{3} / \mathrm{PMH}(3072.6 \mathrm{bd} \mathrm{ft} / \mathrm{PMH})$ and 358.47 $\mathrm{ft}^{3} / \mathrm{SMH}(2150.82 \mathrm{bd} \mathrm{ft/SMH})$ with a weekly production of $14338.8 \mathrm{ft}^{3}(86032.8 \mathrm{bd} \mathrm{ft})$. Costs of the grapple skidder including labor were $\$ 83.09 / \mathrm{PMH}$ and $\$ 56.51 / \mathrm{SMH}$ with a weekly cost of $\$ 2260.40$. Cost of the grapple skidder was the second highest of machines examined.

\subsection{System Comparison}

The two harvesting systems were compared based on their cost and production. To do this, the systems had to be balanced first. Calculations for production and cost of balanced systems are contained in Table 4.1. The first step to balancing harvesting systems is to know the production rate of each function in volume per productive machine hour. Multiplying the mechanical availability of a machine to this production provides us with a volume per scheduled machine hour. Examining those volumes per $\mathrm{SMH}$, a decision of how many of each machine is needed to balance the system. The goal is to get an equal production per SMH for each harvesting function in the system. For example, in the case of the mechanized harvesting system, volume per SMH for the feller-buncher is over twice that of top/delimbing or grapple skidding (Table 4.1). Therefore, it was decided that there needs to be 2 top/delimbers and 2 grapple skidders 
for every one feller-buncher. The feller-buncher volume per SMH is not quite 3 times as much as the others and you can only have whole numbers for pieces of equipment so 3 pieces of equipment are not needed for any one function. The manual harvesting system had nearly equal volume per SMH for felling and skidding so one machine per function was all that was needed to balance the system.

Multiplying the number of machines performing a harvesting function by the volume per SMH of a single machine provides the total volume per SMH produced by that function. The manual system had one of each machine performing the functions so volume per SMH stayed the same. The mechanized harvesting functions, however, had multiple machines in some cases so a new volume per SMH for top/delimbing and grapple skidding was calculated. The limiting function, or function with the lowest production rate per $\mathrm{SMH}$, then needs to be identified in each system. Chainsaw felling was the limiting function in the manual harvesting system with a production of 181.70 $\mathrm{ft}^{3} / \mathrm{SMH}$ (1090.2 bd $\mathrm{ft}$ ) while grapple skidding was the limiting function in the mechanized harvesting system with a production of $716.94 \mathrm{ft}^{3} / \mathrm{SMH}(4301.64 \mathrm{bd} \mathrm{ft})$. Utilization of each function then needs to be found and is calculated by using the equation:

$$
\mathrm{UT} \%=\text { System rate/ }\left(\# \text { of machines } * \mathrm{ft}^{3} / \mathrm{PMH}\right)
$$


Where UT is the utilization of each function, system rate is the production rate per $\mathrm{SMH}$ of the limiting function, and $\mathrm{ft}^{3} / \mathrm{PMH}$ is the production of a single machine. For example, when calculating cable skidder UT, the equation would look like:

$$
\mathrm{UT}=181.70 /(1 * 289.40)=63 \%
$$

By multiplying the utilization rate of each function by the operating cost in $\$ / \mathrm{PMH}$ for the corresponding machine, a $\$ / \mathrm{SMH}$ cost for that machine is then calculated. Adding fixed, variable and labor cost per SMH for an individual machine and multiplying that total by the number of machines performing each harvesting function provides a total cost per SMH for each function. Dividing that total cost per SMH for each function by the system rate provides a unit cost for each function. Then the costs for the functions can be added to get a unit cost for each system. Total system costs of $\$ 0.36 / \mathrm{ft}^{3}(\$ 0.06 / \mathrm{bd}$ $\mathrm{ft}$ ) and $\$ 0.29 / \mathrm{ft}^{3}(\$ 0.05 / \mathrm{bd} \mathrm{ft})$ were found for the manual and mechanized harvesting systems, respectively (Table 4.1). The manual harvesting system had much lower cost per SMH than the mechanized system, but because the mechanized system was so much more productive than the manual system, it had a lower unit cost. Multiplying the manual harvesting system rate of $181.70 \mathrm{ft}^{3} / \mathrm{SMH}$ (1090.2 bd ft/SMH) by 40 hours per workweek provides a weekly production of $7268 \mathrm{ft}^{3}$ (43608 bd ft) for the manual harvesting system. Similarly, multiplying the mechanized harvesting system rate of $716.94 \mathrm{ft}^{3} / \mathrm{SMH}$ (4301.64 bd ft/SMH) by 40 hours per workweek provides a weekly production of $28677.6 \mathrm{ft}^{3}$ (172065.6 bd ft) for the mechanized harvesting system. 
Table 4.1 - Production and cost of balanced systems

\begin{tabular}{|c|c|c|c|c|c|c|c|c|c|}
\hline Function & $\overline{f \mathrm{ft}^{3} / \mathrm{PMH}}$ & MA & $\mathrm{ft}^{3} / \mathrm{SMH}$ & $\begin{array}{c}\text { \# of } \\
\text { Machines }\end{array}$ & $\mathrm{ft}^{3} / \mathrm{SMH}$ & UT\% & $\begin{array}{c}\text { Total } \\
\text { Cost/SMH }\end{array}$ & $\$ / \mathrm{ft}^{3}$ & $\begin{array}{c}\text { System } \\
\text { Cost per } \mathrm{ft}^{3}\end{array}$ \\
\hline \multicolumn{10}{|c|}{ Manual Harvesting System } \\
\hline$\overline{\text { Chainsaw Felling }}$ & 363.40 & $50 \%$ & 181.70 & 1 & 181.70 & $50 \%$ & $\$ 14.50$ & $\$ 0.08$ & \\
\hline Cable Skidding & 289.40 & $65 \%$ & 188.11 & 1 & 188.11 & $63 \%$ & $\$ 51.71$ & $\$ 0.28$ & $\$ 0.36$ \\
\hline \multicolumn{10}{|c|}{ Mechanized Harvesting System } \\
\hline Feller-Buncher & 1266.60 & $65 \%$ & 823.29 & 1 & 823.29 & $57 \%$ & $\$ 64.06$ & $\$ 0.09$ & \\
\hline Top/Delimb & 726.30 & $50 \%$ & 363.15 & 2 & 726.30 & $49 \%$ & $\$ 28.22$ & $\$ 0.04$ & \\
\hline Grapple Skidding & 512.10 & $70 \%$ & 358.47 & 2 & 716.94 & $70 \%$ & $\$ 113.01$ & $\$ 0.16$ & $\$ 0.29$ \\
\hline
\end{tabular}

\subsection{Discussion}

Production and cost are always major factors in choosing a harvesting system to operate. If a logger cannot produce enough volume to support the cost of operation, the business will lose money and be forced to shut down. Many loggers are hesitant to devote high investment costs into a harvesting system, especially if they have doubts that it will produce the volume needed to profit. The findings in this study show that, although the mechanized harvesting system requires much higher cost per SMH to operate, its cost per unit volume is not too high due to its extremely high output of volume. Mechanized systems are much safer than manual ones, minimizing the number of people working on the ground. Discounts in workers compensation rates are even being given to mechanized harvesting operations which can lower the high cost of that system.

Cost and productivity, however, are not the only factors when making the decision to invest in a mechanized harvesting system. Supply of standing timber is also 
important due to the fact that the productive mechanized system needs to be feed with standing trees. If there isn't enough timber to cut, the mechanized system will have very expensive downtime. Also terrain is a big factor in choosing the mechanized system. The feller-buncher can operate on relatively steep slopes but manual felling can be conducted on much steeper ground. If the majority of the terrain is very steep, a mechanized operation may not be the best choice. Obviously, both systems have a place in the Appalachian hardwood region. Loggers have operated manual systems in this region for a long time and mechanized systems are now gaining in popularity where they can be used feasibly. As with manual systems, there is a threshold as to how many mechanized systems a given area can support. If a logger chooses to operate a mechanized system, a location that can support the system in terms of timber and slope must be considered in addition to the production and cost. Because of its lower unit cost of production, it is recommended that the move from a manual to mechanized harvesting system be made if all requirements of timber supply, terrain, and startup costs can be met. 


\section{REFERENCES}

Avery, T. E. and H. E. Burkhart. 2002. Forest Measurements. 5th Ed. McGraw-Hill, New York. $456 \mathrm{p}$.

Baumgras, John E., and Penn A. Peters. 1985. Cost and production analysis of the bitterroot miniyarder on an Appalachian hardwood site. Research Paper NE-557. Broomall, PA: U.S.D.A Forest Service, Northeastern Forest Experiment Station; 13 p.

Blinn, C.R., S.A. Sinclair, C.C. Hassler, and J.A. Mattson. 1986. Comparison of productivity, capital, and labor efficiency of five timber harvesting systems for northern hardwoods. Forest Prod. J. 36(10):63-69

Brinker, Richard W., John F. Klepac, Bryce J. Stokes, and Joe D. Roberson. 1996. Effect of Tire Size on Skidder Productivity. Proceedings: Certification-Environmental implications for forestry operations; 1996 September 9-11; Quebec City, Quebec.

Brock, Samuel M., Kenneth D. Jones, and Gary W. Miller. 1986. Felling and Skidding Costs Associated With Thinning a Commercial Appalachian Hardwood Stand in Northern West Virginia. North. J. Appl. For. 3:159 - 163.

Fisher, Edward L., Harry G. Gibson, and Cleveland J. Biller. 1980. Production and Cost of a Live Skyline Cable Yarder Tested in Appalachia. Research Paper NE-465. Broomall, PA: U.S.D.A. Forest Service, Northeastern Forest Experiment Station. 
Gibson, David F., and John H. Rodenberg. 1975. Time Study Techniques for Logging Systems Analysis. General Technical Report INT-25. Ogden, UT: U.S.D.A. Forest Service, Intermountain Forest \& Range Experiment Station.

Greene, W.D. and J.F. McNeel. 1991. Productivity and cost of sawhead feller-bunchers in the Forest Prod. J. 41(3):21-26.

Hassler, Curt C, Shawn T. Grushecky, Chris B. LeDoux. 2000. The Effects of Group Selection Harvest Size on Logging Productivity. North. J. Appl. For. 17(2):51-56.

Howard, Andrew F. 1987. Modeling the Cost and Profitability of Timber Harvesting with Cable Skidders. North. J. Appl. For. 4:87-92.

Howard, Andrew F. 1989. A sequential approach to sampling design for time studies of cable yarding operations. Can. J. For. Res. 19:973-980.

Howard, Andrew F., and Robert Gasson. 1991. A system for computer-based design and implementation of time studies. Forest Prod. J. 41(7/8):53-55.

Howard, Andrew F., Guillaume Thérien. 1989. Regression analysis using auxiliary information from time studies of cable yarding operations. Can. J. For. Res. 19:12621266. 
Huyler, Neil K., and Chris P. LeDoux. 1991. A comparison of small tractors for thinning central hardwoods. In Proceedings of the $8^{\text {th }}$ Central Hardwood Forest Conference.

Jones, Kenneth D. 1983. Time study analysis of three thinning treatments in mixed oakcove hardwood stands in Northern West Virginia. Master's Thesis. West Virginia University Division of Forestry.

Kluender, R. A., and B. J. Stokes. 1996. Felling and skidding productivity and harvesting cost in Southern Pine Forest. In: Proceedings: Certification-Environmental implications for forestry operations; 1996 September 9-11; Quebec City, Quebec; joint conference Canadian Woodlands Forum, Canadian Pulp and Paper Association, and International Union of Forest Research Organizations: 35-39.

Kluender, R.; Lortz, D.; McCoy, W.; Stokes, B.; Klepac, J. 1997. Productivity of rubbertired skidders in southern pine forests. Forest Prod. J. 47(11/12): 53-58.

Kochenderfer, J.N. and G.W. Wendel. 1980. Costs and Environmental Impacts of Harvesting Timber in Appalachia with a Truck-mounted Crane. USDA Forest Service Research Paper NE-456.

Lanford, Bobby L. and Bryce J. Stokes, 1996. Comparison of two thinning systems. Part 2. Productivity and costs. Forest Prod. J. 46(11/12):47-53. 
LeDoux, Chris B. 1985. When is hardwood cable logging economical? Journal of Forestry. 83(5):295-8.

LeDoux, C. B. 1985. Stump-to-mill timber production cost equations for cable logging eastern hardwoods. Res. Pap. NE-566. Broomall, PA: U.S. Department of Agriculture, Forest Service, Northeastern Forest Experiment Station. 6 p.

LeDoux, Chris B. 1987. Estimating yarding costs for the Clearwater cable yarder. Res. Pap. NE-609. Broomall, PA: U.S. Department of Agriculture, Forest Service, Northeastern Forest Experiment Station. 4 p.

LeDoux, C. B.; Butler, D. A. 1981. Simulating cable thinning in young-growth stands. Forest Science. 27(4):745-757.

LeDoux, Chris B.; Huyler, Neil K. 2000. Cost comparisons for three harvesting systems operating in northern hardwood stands. Res. Pap. NE-715. Newtown Square, PA: U.S. Department of Agriculture, Forest Service, Northeastern Research Station. 4 p.

Lortz, D.; R. Kluender,; W. McCoy,; B. Stokes, and J. Klepac,: 1997. Manual felling time and productivity in southern forests. Forest Products Journal. 47(10): 59-63.

McDonald, T.P., R.B. Rummer, and S.E. Taylor. 2000. Automated time study of fellerbunchers. In Proceedings of the Council on Forest Engineering $23^{\text {rd }}$ Annual Meeting. 
McNeel, J. F., and K. K. Dodd. 1997. Improving Cable Thinning System Productivity by Modifying Felling Phase Operations. Jrnl. For. Eng. 8(2):47-56.

Miyata, E.S. 1980. Determining fixed and operating costs of logging equipment. Gen. Tech. Rept. NC-55. USDA Forest Serv., St. Paul, MN.

Peters, P.A. 1990. The load curve intercept method: estimating the effect of average piece size on skidding cost. ASAE Paper No. 88-7546. St. Joseph, MI: ASAE

Sarles, R.L. and K.R.Whitenack, 1984. Costs of logging thinnings and a clearcutting in Appalachia using a truck-mounted crane. U.S. For. Serv., Research Paper NE-545. 9pp.

Shaffer, R.M., K. R. Brummel, T. W. Reisinger and B. J. Stokes. 1993. Impact of group selection silviculture on timber harvesting productivity and cost Northern Journal of Applied Forestry 10(4):170-174.

Shaffer, R.M., and J.S. Milburn. 1999. Injuries on feller-buncher / grapple skidder logging operations in the southeastern United States. Forest Prod. J. 49(7/8):24-26.

Stuart, W.B. 1981. Harvesting analysis technique: A computer simulation system for timber harvesting. Forest Prod. J. 31(11):45-53. 
Wang, J., J. McNeel, and J. Baumgras. 2003 A computer-based time study system for harvesting operations. Forest Prod. J. 53(3): 47-53

Wang, J., W. D. Greene, and B. J. Stokes. 1998. Stand, harvest, and equipment interactions in simulated harvesting prescriptions. Forest Prod. J. 48(9): 81-86.

Wang, J. and R. Haarlaa. 2002. Production analysis of an excavator-based harvester: a case study in Finnish forest operations. Forest Prod. J. 52(3): 85-90

Wilhoit, J. and B. Rummer. 1999. Application of small-scale systems: evaluation of alternatives. Paper no. 99-5056 In: Proceedings of the ASAE/CSAE-SCGR Annual International Meeting, Toronto, Canada. $18 \mathrm{p}$. 


\section{APPENDIX A: TIME STUDY DATA LOGGER INFORMATION}

Time Study Data Logger is a Windows CE-based computer program created by Jingxin Wang of West Virginia University. The program allows collection of time study data using a handheld computer and upload of the data to a desktop pc. Below is a list windows within the program that allow species design, addition of harvesting functions and factors, and collection of site information and elemental times and variables (Figure A1). Also included is an image of each window in use. Time Study Data Logger Help includes:

(1) Design Species

(2) Design Harvesting Functions

(3) Design Harvesting Factors

(4) Collect Site Information

(5) Collect Harvesting Elemental Times and Variables 

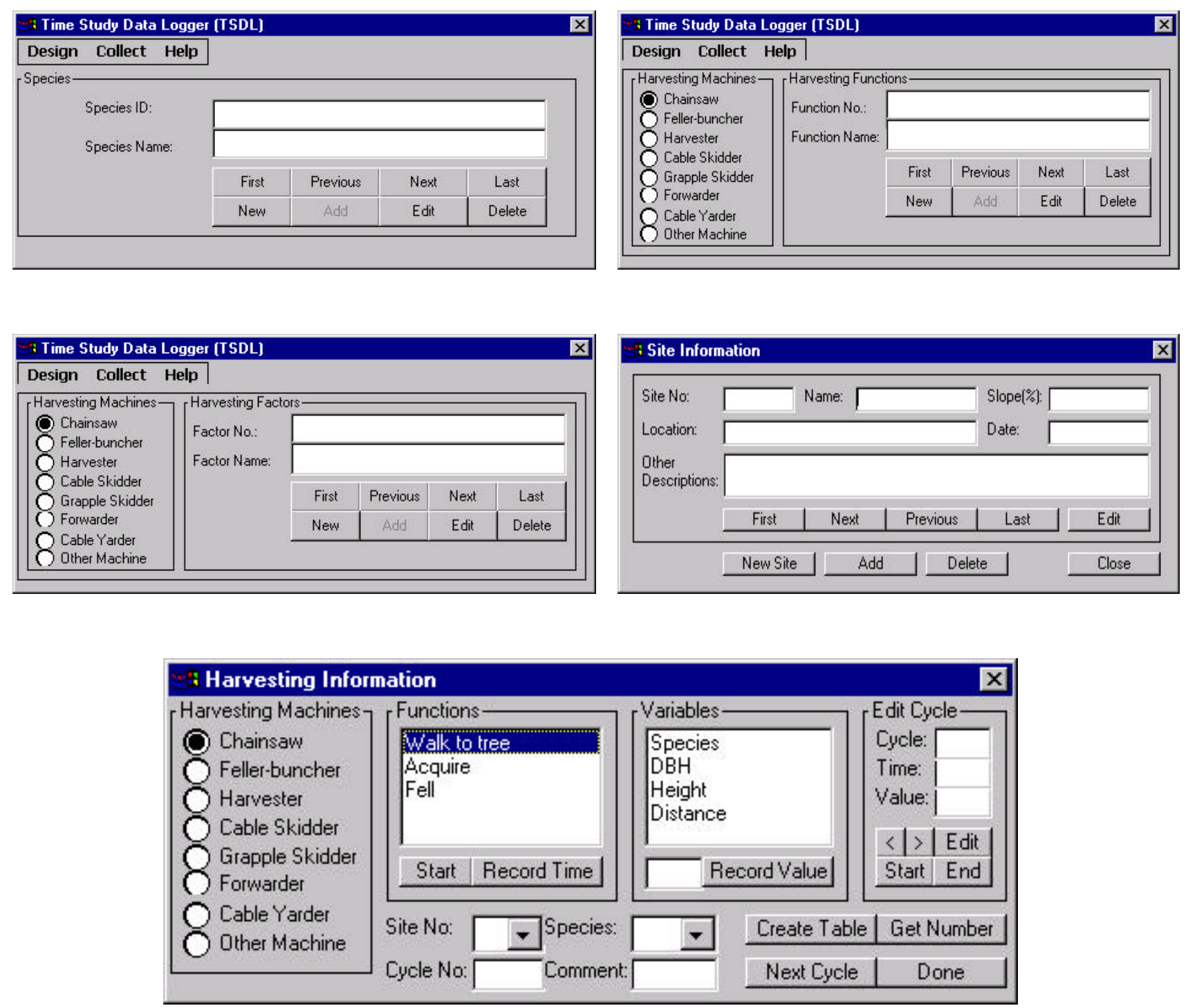

Figure A1. Some main forms in Windows CE-based time study system 


\section{APPENDIX B: DATA COLLECTION SHEETS}

\section{Manual Felling Sheet}

\begin{tabular}{|c|c|c|c|c|c|c|c|c|c|c|}
\hline Cycle \# & Walk (min) & Walk (ft) & $\begin{array}{c}\begin{array}{c}\text { Acquire } \\
\text { (min) }\end{array} \\
\end{array}$ & Cut (min) & Top (min) & Species & DBH (in) & Length (ft) & Delay (min) & Comment \\
\hline & & & & & & & & & & \\
\hline & & & & & & & & & & \\
\hline & & & & & & & & & & \\
\hline & & & & & & & & & & \\
\hline & & & & & & & & & & \\
\hline & & & & & & & & & & \\
\hline & & & & & & & & & & \\
\hline & & & & & & & & & & \\
\hline & & & & & & & & & & \\
\hline & & & & & & & & & & \\
\hline & & & & & & & & & & \\
\hline & & & & & & & & & & \\
\hline & & & & & & & & & & \\
\hline & & & & & & & & & & \\
\hline & & & & & & & & & & \\
\hline & & & & & & & & & & \\
\hline & & & & & & & & & & \\
\hline & & & & & & & & & & \\
\hline & & & & & & & & & & \\
\hline & & & & & & & & & & \\
\hline & & & & & & & & & & \\
\hline & & & & & & & & & & \\
\hline & & & & & & & & & & \\
\hline & & & & & & & & & & \\
\hline & & & & & & & & & & \\
\hline & & & & & & & & & & \\
\hline
\end{tabular}




\section{Cable Skidding Sheet}

\begin{tabular}{|c|c|c|c|c|c|c|c|c|c|c|}
\hline Cycle \# & EMPTY(min) & DIST (ft) & CHOKE (min) & LOADED $(\min )$ & UNCHOKE $(\mathrm{min})$ & Species & DBH (in) & LEN (ft) & DELAY (min) & COMMENTS \\
\hline & & & & & & & & & & \\
\hline & & & & & & & & & & \\
\hline & & & & & & & & & & \\
\hline & & & & & & & & & & \\
\hline & & & & & & & & & & \\
\hline & & & & & & & & & & \\
\hline & & & & & & & & & & \\
\hline & & & & & & & & & & \\
\hline & & & & & & & & & & \\
\hline & & & & & & & & & & \\
\hline & & & & & & & & & & \\
\hline & & & & & & & & & & \\
\hline & & & & & & & & & & \\
\hline & & & & & & & & & & \\
\hline & & & & & & & & & & \\
\hline & & & & & & & & & & \\
\hline & & & & & & & & & & \\
\hline & & & & & & & & & & \\
\hline & & & & & & & & & & \\
\hline & & & & & & & & & & \\
\hline
\end{tabular}




\section{Feller-buncher Felling Sheet}

\begin{tabular}{|c|c|c|c|c|c|c|c|c|c|c|c|c|}
\hline Cycle \# & DriveT(min) & Cut(min) & DriveD(min) & Dump(min) & DistT(ft) & DistD(ft) & Bunch(min) & \begin{tabular}{|l|} 
Delay $(\min )$ \\
\end{tabular} & \begin{tabular}{|c|} 
Comments \\
\end{tabular} & Species & Diam(in) & Len(ft) \\
\hline & & & & & & & & & & & & \\
\hline & & & & & & & & & & & & \\
\hline & & & & & & & & & & & & \\
\hline & & & & & & & & & & & & \\
\hline & & & & & & & & & & & & \\
\hline & & & & & & & & & & & & \\
\hline & & & & & & & & & & & & \\
\hline & & & & & & & & & & & & \\
\hline & & & & & & & & & & & & \\
\hline & & & & & & & & & & & & \\
\hline & & & & & & & & & & & & \\
\hline & & & & & & & & & & & & \\
\hline & & & & & & & & & & & & \\
\hline & & & & & & & & & & & & \\
\hline & & & & & & & & & & & & \\
\hline & & 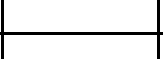 & & & 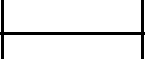 & & & & & & & \\
\hline & & & & & & & & & & & & \\
\hline & & & & & & & & & & & & \\
\hline & & & & & & & & & & & & \\
\hline & & & & & & & & & & & & \\
\hline & & & & & & & & & & & & \\
\hline & & & & & & & & & & & & \\
\hline & & & & & & & & & & & & \\
\hline & & & & & & & & & & & & \\
\hline & & & & & & & & & & & & \\
\hline & & & & & & & & & & & & \\
\hline
\end{tabular}




\section{Top/Delimbing Sheet}

\begin{tabular}{|c|c|c|c|c|c|c|}
\hline Cycle \# & Top/Delimb (min) & Species & Diameter (in) & Length (ft) & Maintenance (min) & Comments \\
\hline & & & & & & \\
\hline & & & & & & \\
\hline & & & & & & \\
\hline & & & & & & \\
\hline & & & & & & \\
\hline & & & & & & \\
\hline & & & & & & \\
\hline & & & & & & \\
\hline & & & & & & \\
\hline & & & & & & \\
\hline & & & & & & \\
\hline & & & & & & \\
\hline & & & & & & \\
\hline & & & & & & \\
\hline & & & & & & \\
\hline & & & & & & \\
\hline & & & & & & \\
\hline & & & & & & \\
\hline & & & & & & \\
\hline & & & & & & \\
\hline & & & & & & \\
\hline & & & & & & \\
\hline & & & & & & \\
\hline & & & & & & \\
\hline
\end{tabular}




\section{Grapple Skidding Sheet}

\section{\begin{tabular}{|l|l|l|l|l|l|l|l|l|l|l|}
\hline Cycle \# & EMPTY (min) & DIST (ft) & GRAPPLE (min) & LOADED (min) & RELEASE (min) & Species & DBH (in) & LEN (ft) & DELAY (min) & COMMENTS
\end{tabular}}

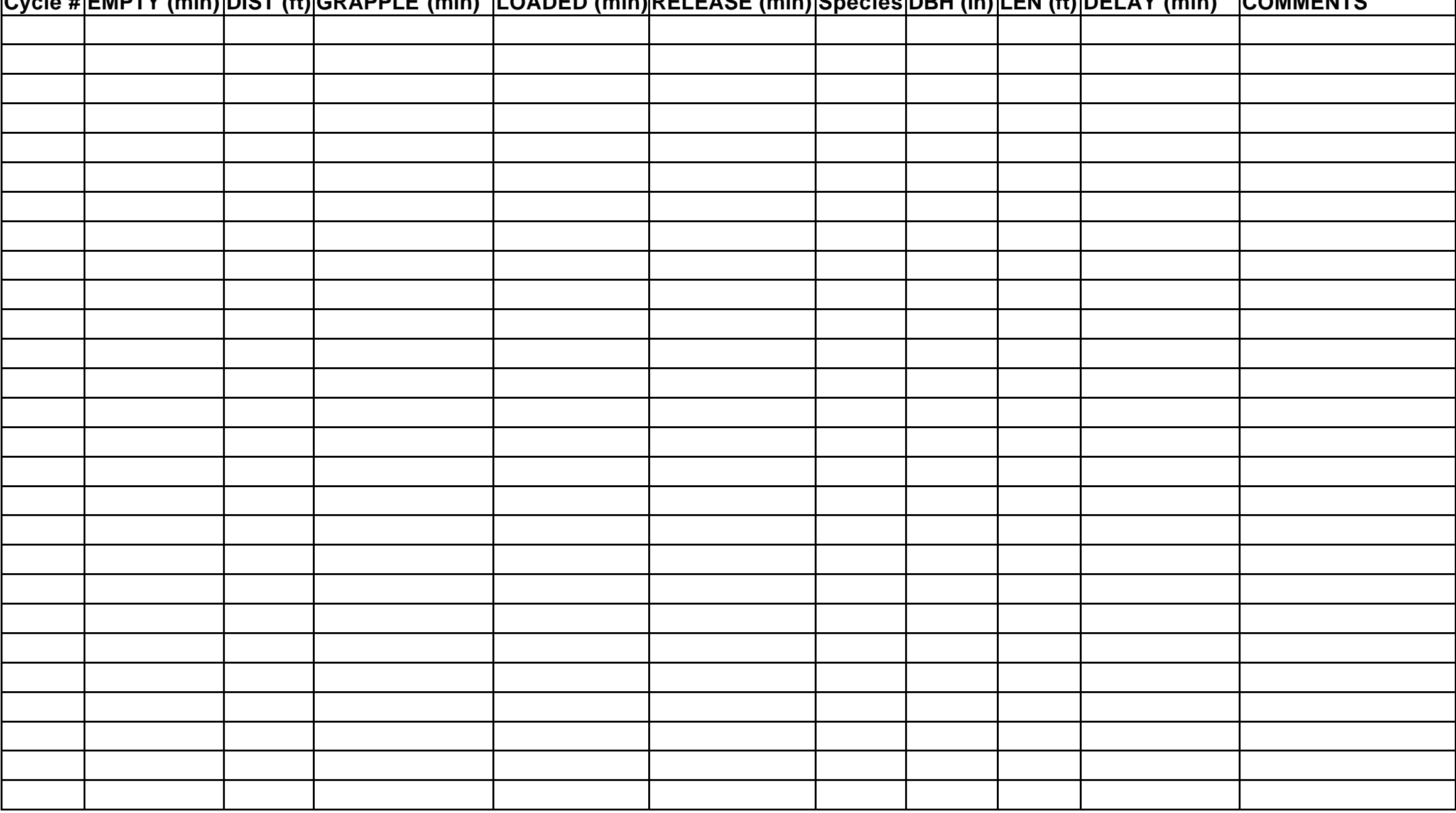




\section{APPENDIX C: SAS CODE USED IN DATA ANALYSIS}

\section{(1) Chainsaw Felling Code}

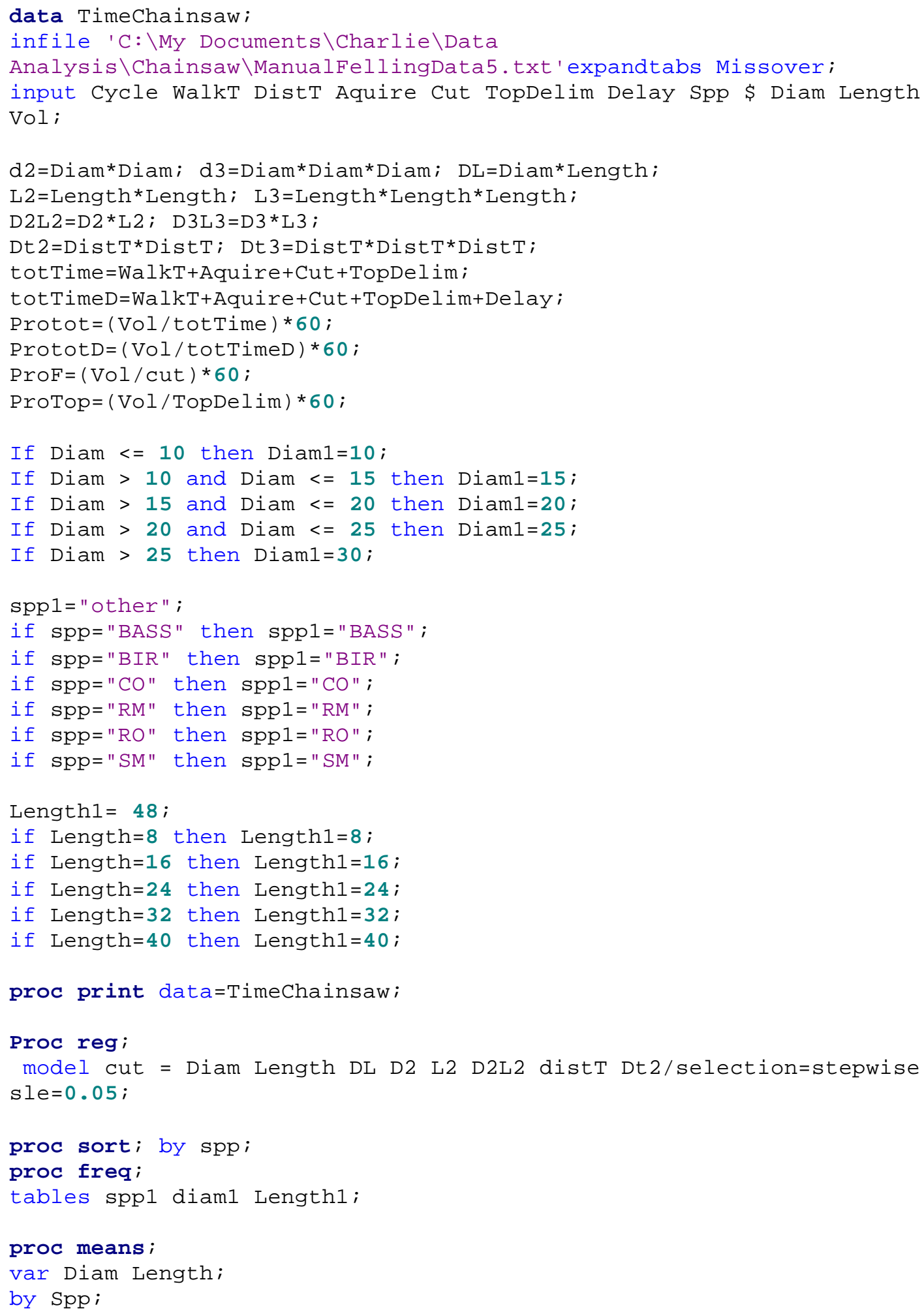




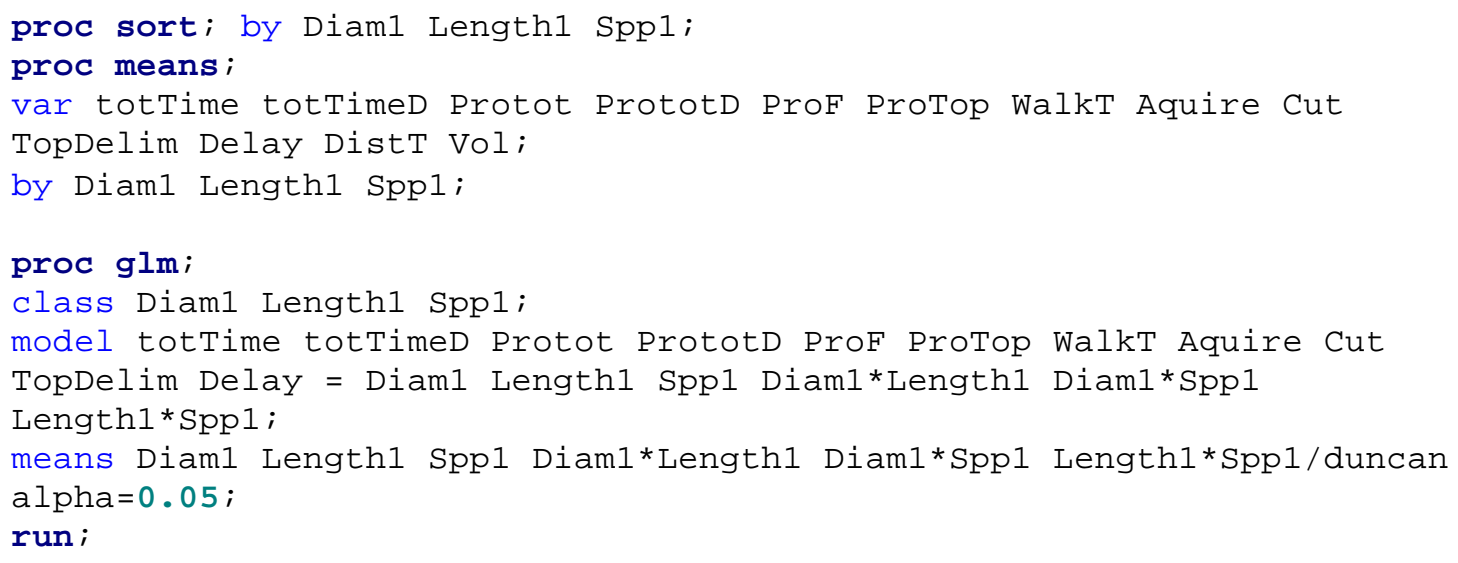

\section{(2) Cable Skidding Code}

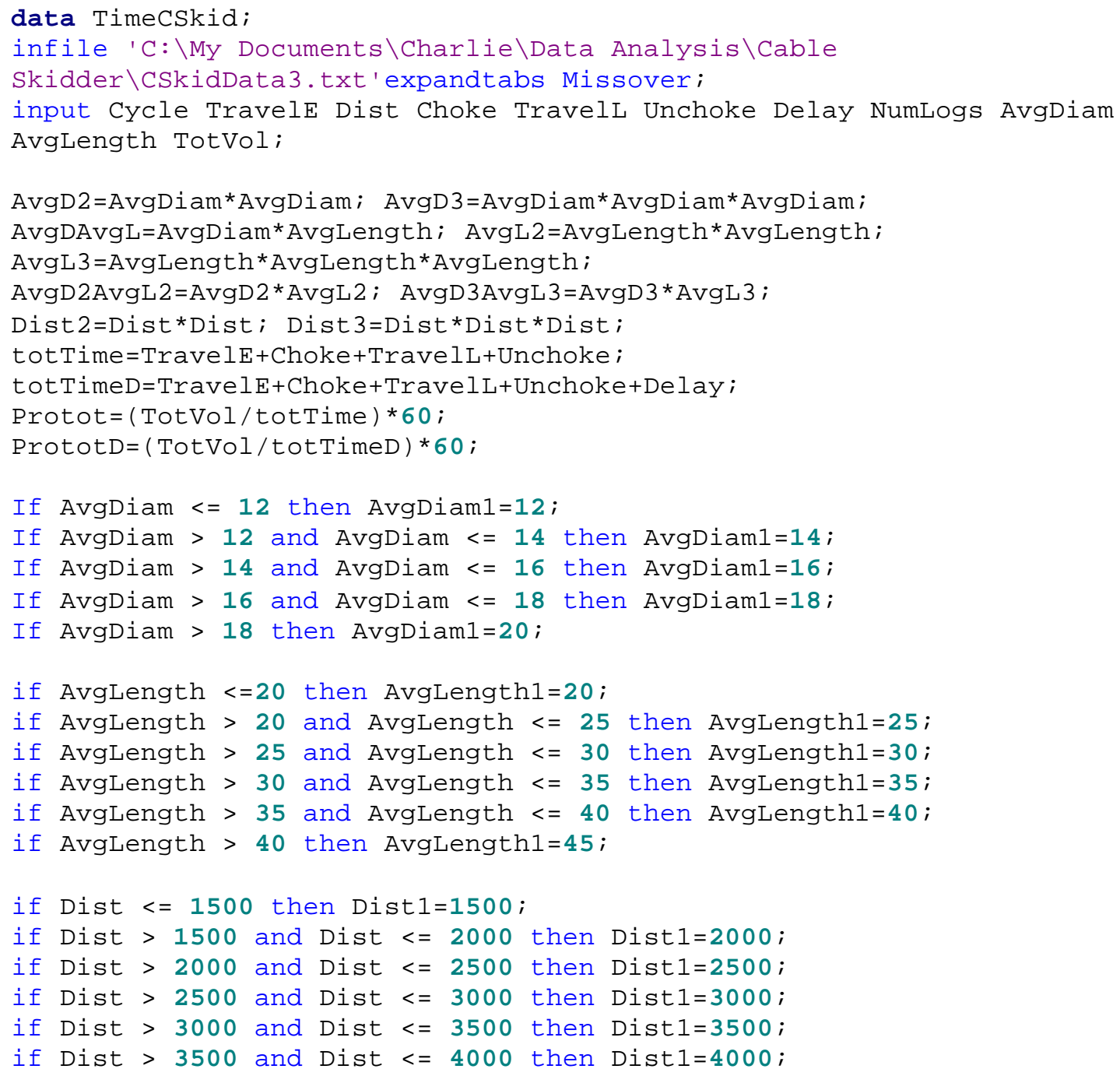




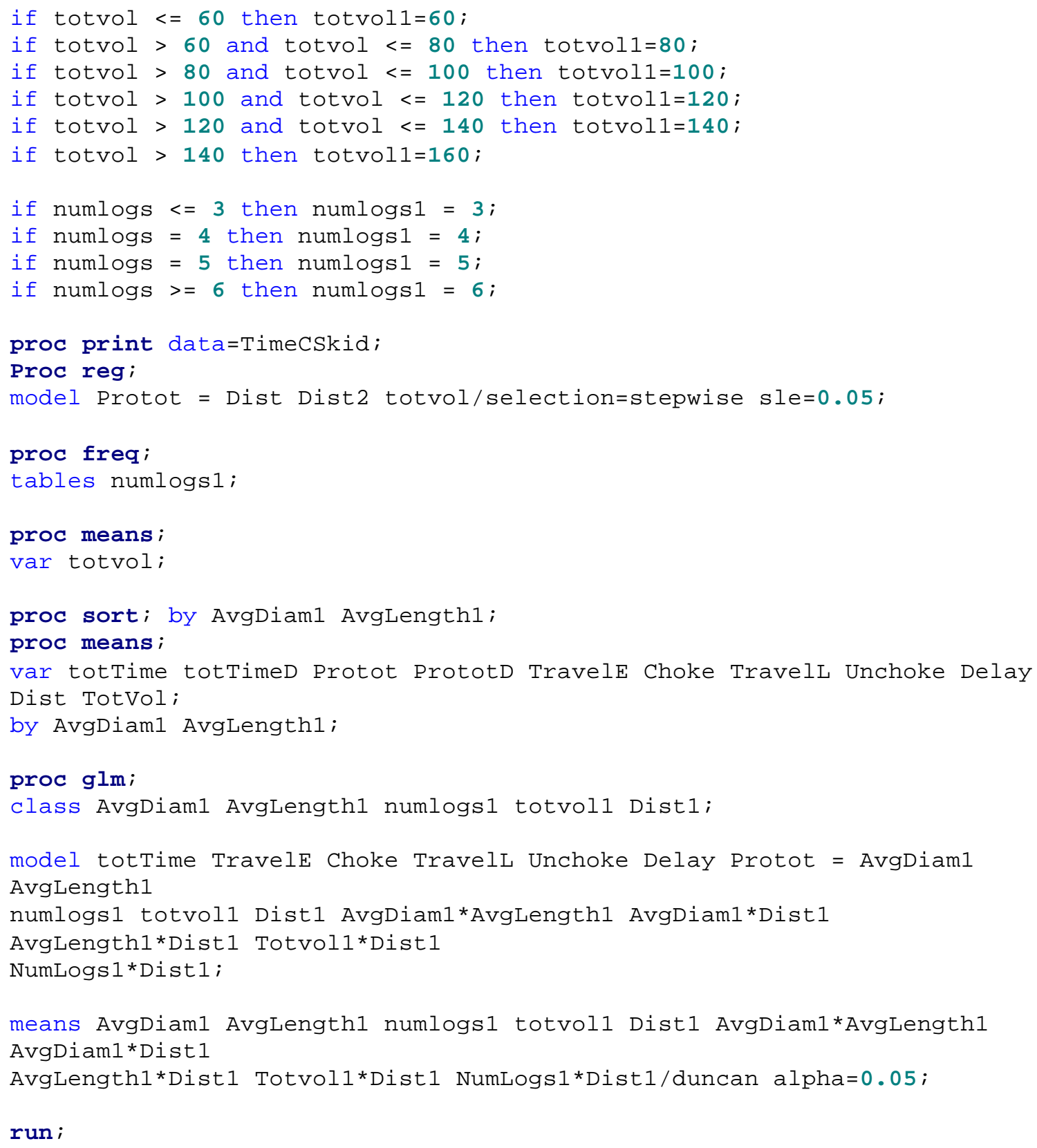

\section{(3) Feller-buncher Felling Code}

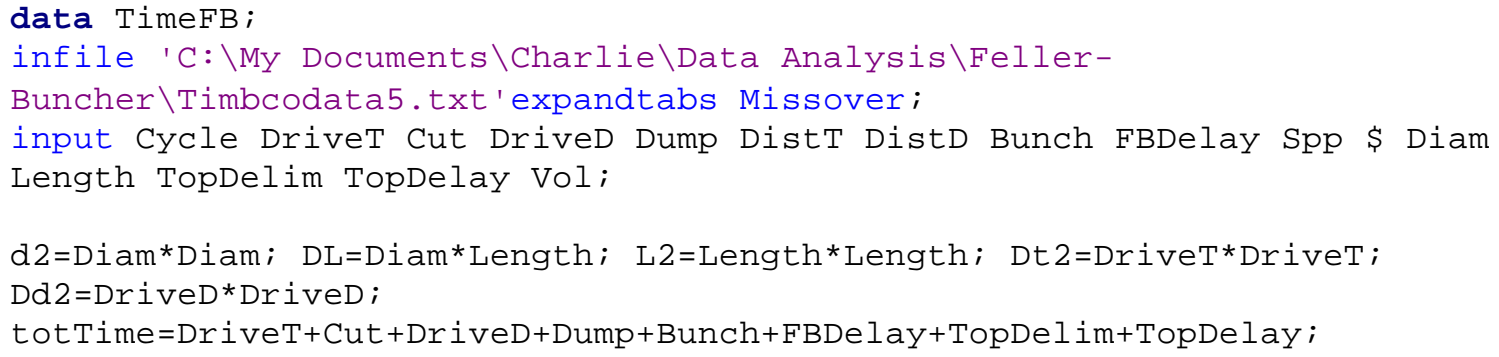




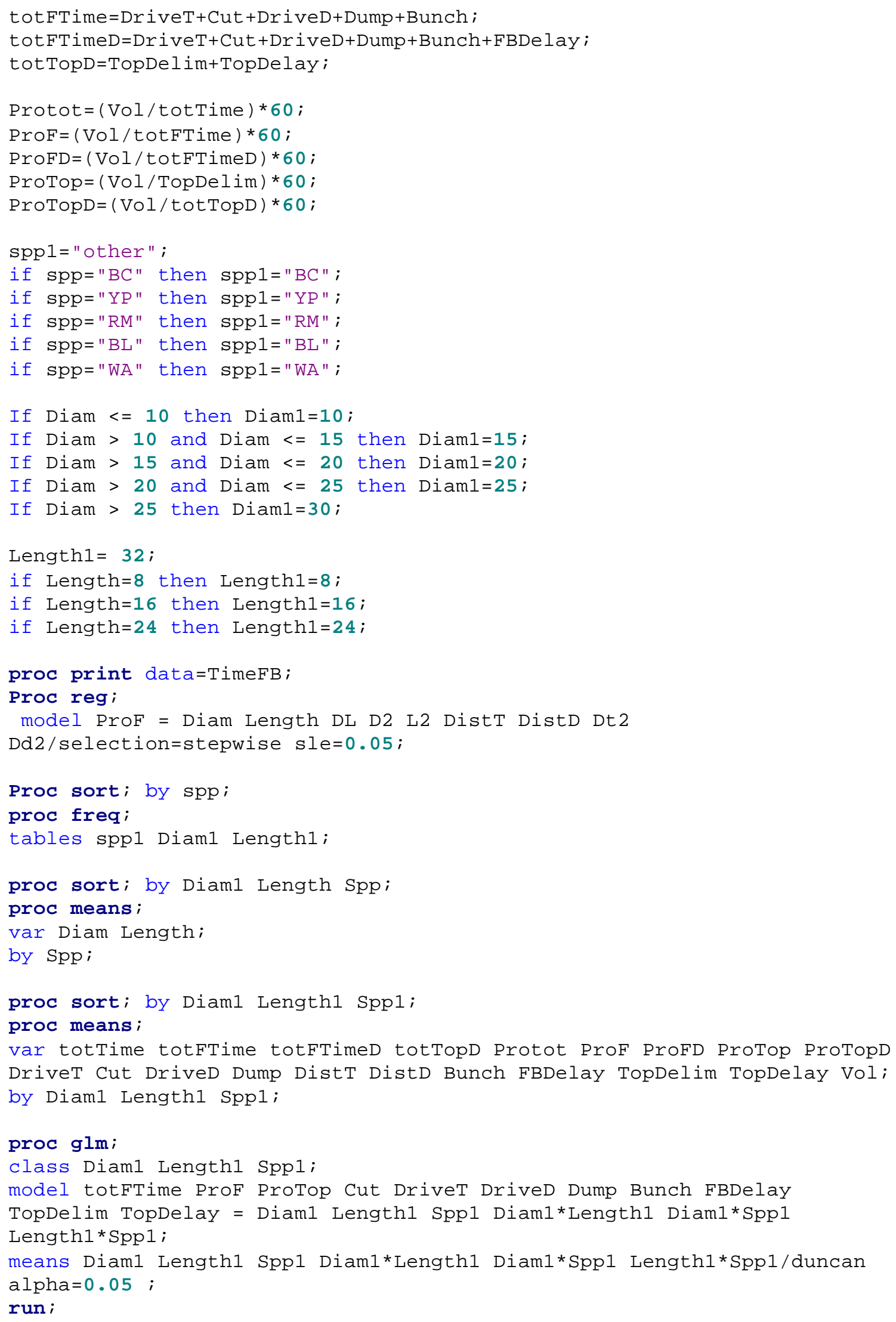




\section{(3) Grapple Skidding Code}

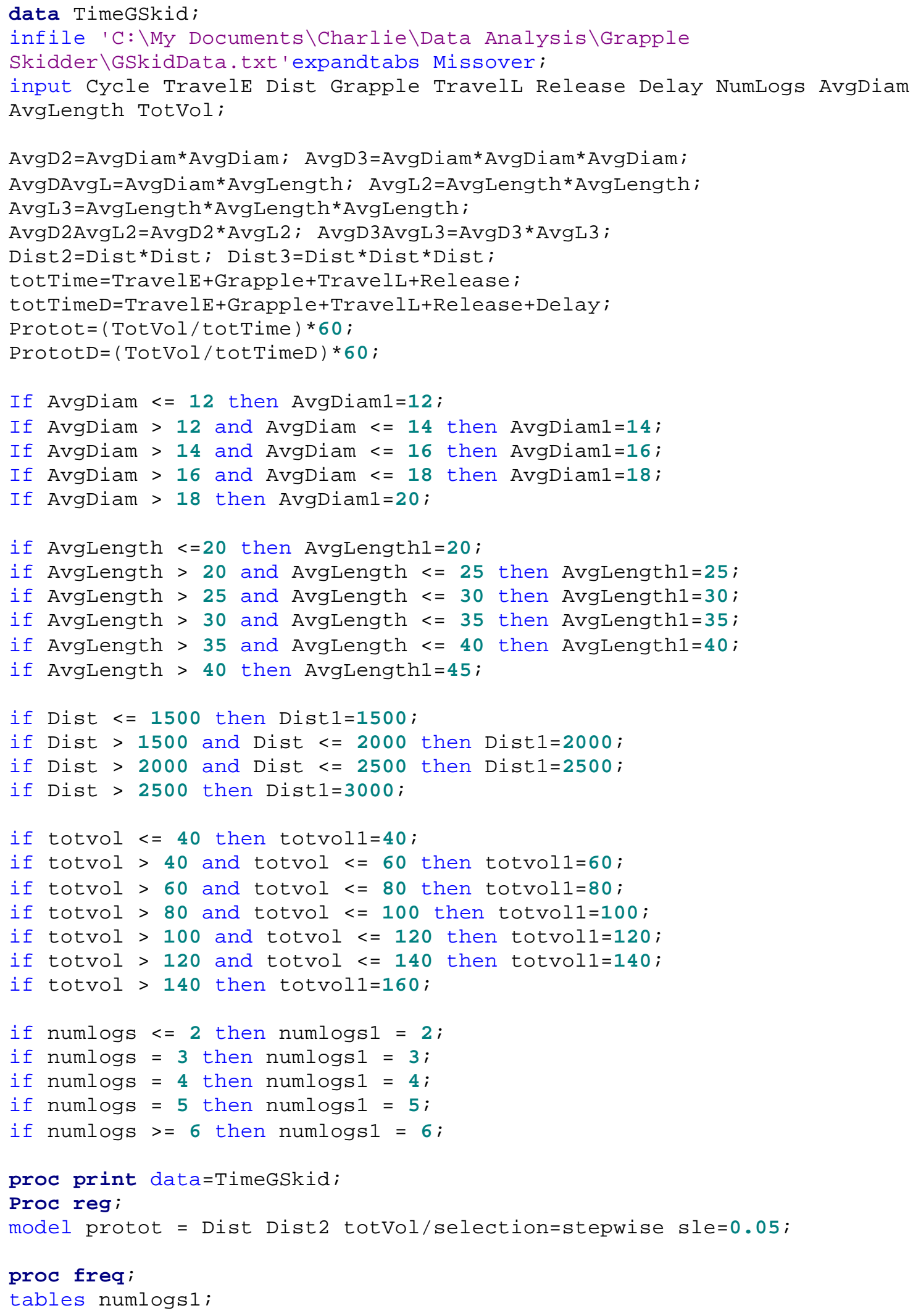




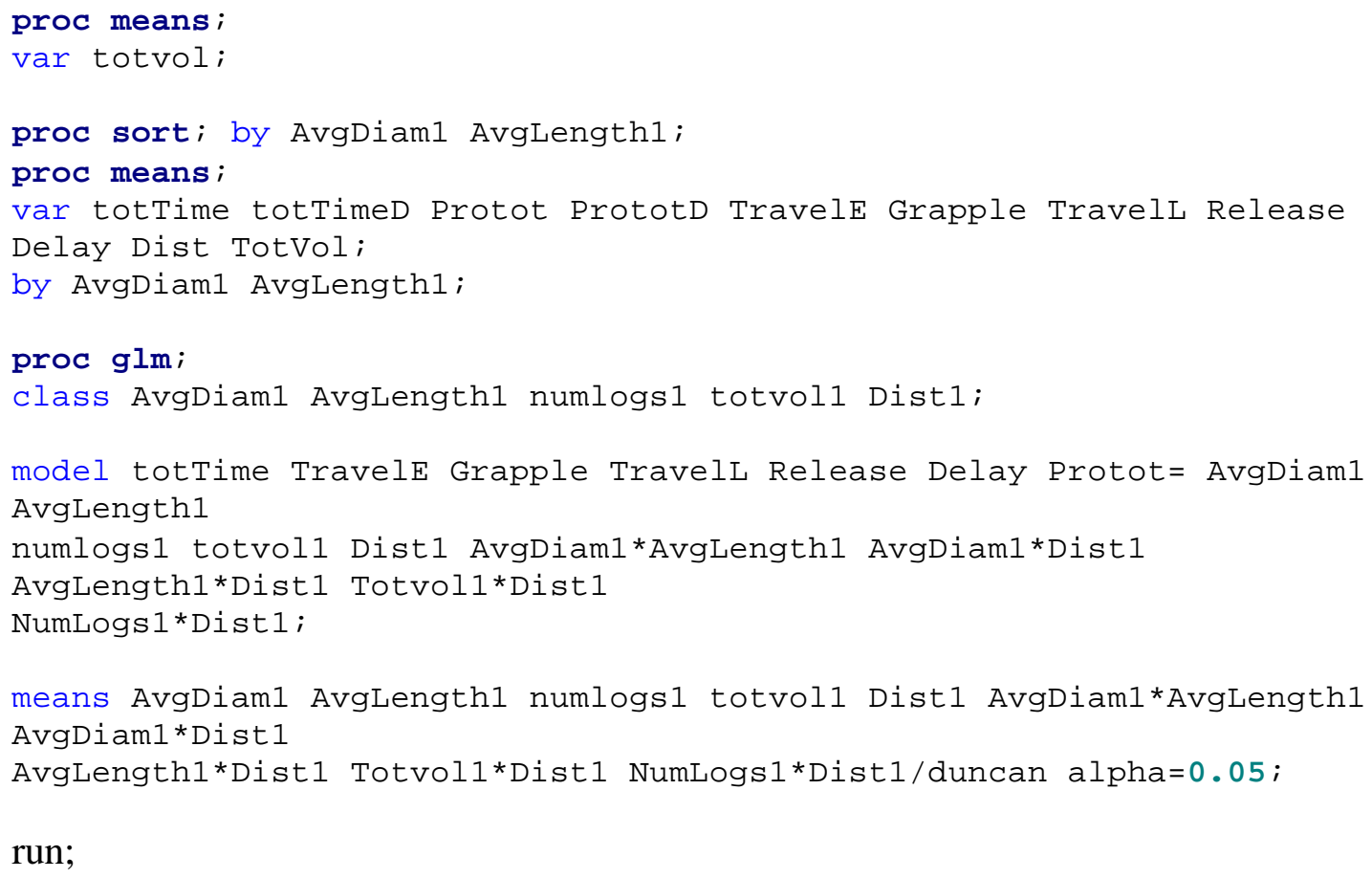

run; 